\title{
İlkokul 4. Sınıf Öğrencilerinin Bilinçli Tüketicilik Durumlarının İncelenmesi*
}

\section{Examining 4th Grade Primary School Students' The Status Of Conscious Consumerism}

\author{
Can Uyanık ${ }^{\text {a,*** }}$
}

a Arş. Gör., Siirt Üniversitesi, Eğitim Fakültesi, Temel Eğitim Bölümü, 56100, Siirt/Türkiye.

ORCID: 0000-0003-1692-6898

\section{MAKALE BILGISII \\ Makale Geçmişi: \\ Başvuru tarihi: 25 Ekim 2019 \\ Düzeltme tarihi: 23 Şubat 2020 \\ Kabul tarihi: 05 Mart 2020}

\section{Anahtar Kelimeler:}

Bilinçli Tüketim

İlkokul

Karma Yöntem

Tüketici Sosyalleşmesi
ÖZ

$\mathrm{Bu}$ araştırmanın amacı, ilkokul dördüncü sınıf öğrencilerinin bilinçli tüketicilik durumlarını incelemektir. Araştırma, karma yöntem yaklaşımıyla tasarlanmıştır. Araştırmanın uygulaması ilkokul Eskişehir'de bulunan 15 ilkokulun 4. sınıf öğrencileri ile gerçekleştirilmiştir. Araştırma kapsamında 478 öğrenciden Bilinçli Tüketicilik Düzeyi Ölçeği aracılığıyla nicel, 15 öğrenciden yarı yapılandırılmış görüşmeler yoluyla nitel veriler elde edilmiştir. Öğrencilerin bilinçli tüketicilik düzeylerinin okulun bulunduğu sosyoekonomik çevreye, annenin ve babanın eğitim düzeyine, ailenin aylık gelir düzeyine, annenin ve babanın mesleki durumuna ve öğrencilerin harçlıklarını biriktirme durumlarına göre anlamlı bir biçimde farklılaştı̆̆ı sonucuna ulaşılmıştır. Sosyoekonomik çevrenin öğrencilerin bilinçli tüketicilik düzeyleri üzerinde etkili bir değişken olduğu belirlenmiştir.

\section{ARTICLE INFO}

Article history:

Received 25 October 2019

Received in revised form 23 February 2020

Accepted 05 March 2020

\section{Keywords:}

Conscious Consumption

Primary School

Mixed Method

Consumer Socialization

\begin{abstract}
A B S T R AC T
The aim of this study was to examine elementary fourth graders' status of conscious consumerism. The present study was designed by adopting the mixed method approach. It was conducted with fourth graders from 15 elementary schools located in the Eskisehir. Quantitative data were gathered from 478 students through Conscious Consumerism Level Scale, and qualitative data from 15 students through semi-structured interviews. It was also found that the fourth grades' levels of conscious consumerism significantly differed based on the socio-economic environment of the school parents' education levels, monthly income of the family, parents' professional state and state of saving their pocket-money. It was found that socio-economic environment was an effective variable on the students' conscious consumerism levels.
\end{abstract}

\section{Giriş}

Günümüz dünyası, birbirinden çok farklı niteliklere sahip insan topluluklarından oluşmaktadır. Bütün bu farklılıklara rağmen bireyleri ortak kılan ve bütün bireylerin doğdukları andan itibaren sahip oldukları, bütün insanları kapsayıcı bir üst kimlik karşımıza çıkmaktadır. Ferman'a (1993) göre insanların, 1rk, renk, din, siyasal görüş ve benzeri unsurlardan bağımsız biçimde taşıdıkları evrensel kimlik, paylaştıkları ortak yazgı, tüketici olmalarıdır. Bireylerin tüketici kimliğini edinmeleri, doğumla birlikte başlayan ve yaşamsal faaliyetlerinin son bulduğu ana kadar geçen zaman dilimini kapsar.

Tüketici olarak bireylerin davranışları tüketim olgusunun ortaya çıkışıyla eş zamanlı olarak birçok unsur tarafindan yönlendirilmeye başlanmıştır. İlkel zamanlarda açlık ve barınma gibi temel içgüdüsel dürtülerin etkisiyle şekillenen tüketici davranışları, günümüze gelindikçe değişen birey ve toplum özellikleri, gelişen teknoloji ve artan insan nüfusuna

\footnotetext{
*Bu çalışma yazarın 2015 yılında Dr. Pelin Yalçınoğlu danışmanlığında Anadolu Üniversitesi Eğitim Bilimleri Enstitüsü İlköğretim Anabilim Dalı'nda yürüttüğü “İlkokul 4. Sınıf Öğrencilerinin Bilinçli Tüketicilik Durumlarının İncelenmesi” başlıklı yüksek lisans tezinden türetilmiştir.

**Sorumlu yazar/Corresponding author

e-posta: can.uyanik@siirt.edu.tr
} 
paralel olarak, çok farklı ve karmaşık ilişkiler halindeki değişkenlerin etkisi altında biçimlenmiştir. Tüketicilerin davranışlarının günümüzdeki karmaşık yapısını almasında etkili olan çok sayıda faktör arasında yer alan, üretim ve tüketim sisteminin temelini oluşturan endüstrileşme olgusu; oluşum amacı, gelişimi ve neden olduğu sonuçlar dikkate alındığında tüketim kaynaklı problemlere zemin hazırlaması bakımından önemli bir unsur olmuştur. Hızlı nüfus artışı, tüketim mallarına duyulan talebin artması ve uluslararası ekonomik birikimin yeni yatırım alanları aramaya başlamasının etkisiyle gelişen bir süreç olarak endüstrileşme, özellikle küresel neoliberal ekonominin yarattığ1 sürekli katlanarak büyüme ve sınırsız tüketim hırsı nedeniyle dünyamızı daha kırılgan bir hale getirmiş, sürdürülebilirlikten uzak üretim ve tüketim davranışları baş etmesi güç problemlere yol açmıştır (Taluğ ve Birden, 2014). Gelinen noktada tüketim, bir ihtiyacı karşılama güdüsü olmaktan çıkmış adeta bir kimlik edinme sürecine dönüşmüştür. Tüketimin tanımı, toplum tarafından belirlenen ihtiyaçlar ve bu ihtiyaç karşılama biçimleri açısından yapılmaya başlanmış; çağdaş toplum, üyelerini öncelikle tüketici olarak görürken, üretici kimliği ikinci plana itilir hale gelmiştir. Sosyal alanda bireyin kimlik edinme çabaları yeni sistemin değerlerine göre ne ürettiğinden çok ne tükettiğine göre biçimlenmiştir. Sosyal norma uyabilmek için tüketici olarak birey, piyasanın ihtiyaç duyduğu şekilde tüketime cevap vermesi gerektiğini düşünmeye başlamıştır (Şahin, 2005).

Tüketim üzerine kurgulanan sistemden en fazla etkilenen unsur hiç şüphesiz çevre olmuştur. Avcı toplayıcı toplumdan başlayarak aletlerle doğaya hükmetmeye çalışan birey, zamanla doğayı üretimin bir doğal sermayesi haline dönüştürmüştür. Özellikle 19 yüzyılla beraber ortaya çıkan Sanayi Devrimi, yayılmacı politika izleyen ve yeryüzünün bütün kaynaklarına egemen olmayı arzulayan devletlere kapitalizmin aç ve büyüyen karnını doyurma konusunda sınırsız imkânlar tanımıştır. Sanayi devrimi sonrasında küresel temelde gelişen kapitalist üretim tarzı, sınırsız büyüme ve yayılma arzusu ile el değmemiş birçok ekosisteme girerek, o sistemlerin yok olmasına ve sanayiye teslim olmasına neden olmuştur. İnsan eliyle doğaya bırakılan ekolojik ayak izi; artı değer yaratma ekonomilerinin sınırsız büyüme ve yayılma arzusu ile zaman içerisinde büyümüştür (Taluğ ve Birden, 2014).

Günümüzde kendi ihtiyaçlarımızı karşılama şeklimiz, gelecek nesillerin kendi ihtiyaçlarını karşılayabilme olanağını tehlikeye atacak boyutlara ulaşmıştır. Neoliberal ekonominin dayattığı katlanarak sürekli büyüme arzusu ve bunun dayandırıldığı tüketim esareti, insan uygarlığını bir felakete sürüklemektedir. Sosyal ve ekonomik sürdürülebilirliğin ancak sağlıklı işleyen ekonomik ve ekolojik sistemle var olabileceği gerçeği düşünüldüğünde mevcut durum sürdürülebilir kalkınmaya tamamen aykırıdır. Gelecek nesillerin ihtiyaçlarını karşılama kapasitelerine zarar vermeden bugünün ihtiyaçlarını karşılamak, tüketimi azaltmak ve doğal kaynakların kullanım dengesini gözeten tüketim biçimlerine yönelmekle mümkün olacaktır (World Wildlife Fund, 2012). Bütün bu olumsuzluklar karşısında gelecek kuşaklara kaynakları tükenmiş, biyolojik açıdan yoksullaşmış ve aşırı ısınmış bir gezegen armağan etmemek, ekolojik ayak izimizi küçültmek, yaşam biçimlerimizi ve tüketim alışkanlıklarımızı değiştirmek ve her alanda sürdürülebilirliği yaşantımızın bir parçası haline getirmek için bireylerin tüketim alışkanlıklarının sağlıklı bir zemine oturtulması ihtiyacı her geçen gün daha fazla önem kazanmaktadır. $\mathrm{Bu}$ ihtiyacın karşılanması için bireylerin sahip olması gereken yeterlik ise tüketim bilincidir. Sınırlı olan geliriyle satın aldığ 1 mal ve hizmetlerden en yüksek faydayı sağlamaya çalışma, alışverişin nesnesi değil öznesi olduğunun farkında olma, standardı yüksek, sağlıklı, güvenli ve çevreci ürün seçme olgunluğunu taşıma, satın alma eyleminin öncesinde, sirasında ve sonrasında rasyonel davranışlar sergileme kabiliyeti olarak tanımlanabilecek tüketim bilinci kavramı, günümüz modern toplum bireylerinin sahip olmaları gereken önemli bir niteliktir (Arrkan ve Odabaşı, 1994; Hekimci, 2003).

Bireylerde tüketim bilinci kavramının yerleşmesinde resmi kurum ve kuruluşlar tarafından çıkarılacak yasalar, merkezi ve yerel yönetimlerce gerçekleştirilecek düzenlemeler ve birtakım sosyal kuruluş ve örgütlerin göstereceği çabalar ne kadar mükemmel olursa olsun tek başına yeterli değildir (Karsu, 2013). Bireyin davranış ve değerleri değişmedikçe değişen kanun ve uygulamaların etkisi sınırlı kalacaktır. Tüketicinin korunması için uzun dönemde verim alınabilecek en etkili yol tüketicinin eğitimidir (Arıkan ve Odabaşı, 1994; Aydın, 1981; Babaoğul ve Şener, 2007; Hayta, 2006; Yener, 1990). Ayrıca, eğitim hakk1 tüketicilerin sahip oldukları haklardan bir tanesi olarak uluslararası anlaşma ve düzenlemelerle güvence altına alınmıştır (United Nations, 2003). Ülkemizde ise Anayasanın 172. maddesinde "Devlet, tüketicileri koruyucu ve aydınlatıcı tedbirler alır, tüketicilerin kendilerini koruyucu girişimlerini teşvik eder" ifadesi ile tüketicinin korunması güvence altına alınmıştır. Dolayısıyla, tüketicilere yönelik eğitim faaliyetlerinin gerçekleştirilmesinde ise en önemli görev eğitim kurumlarına düşmektedir.

Her yaş düzeyindeki bireyler için verilebilecek tüketici eğitimi için özellikle çocukluk yılları kritik bir öneme sahiptir. Bireylerde tüketici bilincinin oluşumu, erken yaşlardan itibaren şekillenen ve tüm yaşam süresi boyunca verilen tüketim kararlarını doğrudan etkileyen bir süreci ifade etmektedir. Bireylerin tüketici olarak sosyalleşmeleri çocuklukla birlikte ortaya çıkmaktadır (Cram, \& Ng, 1999; Çiftçi, 2013; John, 1999). Öyle ki günümüzde, toplumun geleceğe ilişkin büyük beklentiler atfettiği, sevilen, korunan ve kollanan bir birey olarak çocuk, ihtiyaç ve taleplerini karşılamak amacıyla yüklendiği tüketici kimliği gereği, tüketim pazarının önemli bir öğesidir. Adına televizyon kanalları kurulan, yaşadığı çağın bir gereği olarak teknolojiyi ve sosyal medyayı etkili kullanan çocuğun tüketim pazarındaki önemi günümüzde daha da artmıştır. Çocuk artık dinlenmesi, bilgilendirilmesi ve ikna edilmesi gereken güçlü bir hedef kitle haline gelmiştir (Aktaş, Özüpek ve Altunbaş, 2011). Sahip olduğu satın alma gücü, çevresindeki bireylerin satın alma kararları üzerine etki edebilme becerisi ve geleceğin potansiyel müşteri kitlesini oluşturması nedeniyle firmaların pazarlama faaliyetlerinin odağında olan çocuk, sürekli bir bilgi bombardımanına maruz kalmaktadır (Mcneal, 1992). Gazeteler, televizyon kanalları ve etkileşim halinde olduğu teknolojiler aracılığıyla maruz kaldığı bilgi bütünü arasından doğru mesajları seçebilmesi, ihtiyaçları doğrultusunda çözümlemeler yaparak akılcı kararlar alabilmesi için çocuğun bilinçli tüketicilik becerisine sahip olması 
gerekmektedir. Karar verirken seçim yapamayan, ihtiyaç belirleme becerisinden yoksun olan çocuğun tüketici olarak etkili ve yararlı kararlar alabilmesi için eğitilmesi gerekir (Makela, \& Peters, 2004; Yener, 1990). Bütün bu etkenler göz önüne alındığında, tüketici eğitiminin özellikle çocukluk yıllarını da içine alan ilkokul döneminde verilmesi, tüketim bilincine sahip bir toplum oluşması adına büyük önem arz etmektedir. Çünkü ilköğretim, bireyleri yetişkin olduklarında alacakları, toplumsal, kültürel ve ekonomik görevler için hazırlayan, bu görevler için en temel bilgi ve becerileri sağlayan bir eğitim basamağıdır (Yaşar, Sözer ve Gültekin, 2000). Bu nedenle bireylerin tüketici bilincine ilişkin deneyimlerinin ilkokul çağında başlaması gerekmektedir (Babaoğul, Aydıner ve Erberber, 1999).

Ülkemizde 2013 yılında yayımlanan 6502 sayılı Tüketicinin Korunması Hakkında Kanun'da tüketicinin eğitimi görevi örgün ve yaygın eğitim kurumlarına verilmiş ve bu kurumların ders programlarının düzenlenmesinden Milli Eğitim Bakanlığı sorumlu tutulmuştur (Tüketicinin Korunması Hakkında Kanun, 2013). İlkokullarda uygulanan öğretim programları arasında doğrudan tüketici eğitimini temele alan bir ders bulunmamakla birlikte, ilkokul programında yer alan derslerin konu alanı ve üniteleri içerisinde öğrencilerin bilinçli tüketicilik düzeylerini geliştirmeyi amaçlayan bazı etkinliklere yer verildiği görülmektedir. İlkokulun ilk üç yılı dikkate alındığında Hayat Bilgisi dersinin öğrencilerde tüketim bilinci geliştirmeye yönelik en kapsamlı ders olduğu ifade edilebilir. Programda belirlenen ünite, kazanım ve becerilerde sıklıkla tüketim bilincine yönelik ifadelere yer verildiği görülmektedir. Fen Bilimleri Dersi Öğretim Programının amaçlarında doğrudan bilinçli tüketiciliğe yönelik ifadelere yer verilmese de programda birey, çevre ve toplum arasındaki karşılıklı etkileşimi fark ettirerek; toplum, ekonomi ve doğal kaynaklara ilişkin sürdürülebilir kalkınma bilincini geliştirmenin amaçlandığı vurgulanmıştır. $\mathrm{Bu}$ kapsamda 3. sınıf düzeyinde bazı üniteler içerisinde yer alan konu ve kazanımlarla, 4. sınıf düzeyinde ise "İnsan ve Çevre" konu alanı içerisinde yer alan "Bilinçli Tüketici" konu alanıyla özellikle beslenme, kaynakların dikkatli kullanımı ve geri dönüşüm bilincinin kazandırılması amaçlanmıştır. Türkçe Dersi Öğretim Programı içerisinde yer alan bazı temalara ait bilgilendirici, hikaye edici ve şiir türündeki metinler aracılığıyla doğrudan olmasa bile dolaylı olarak tüketim bilincinin gelişimine yönelik öğrencilerin davranışlarının biçimlendirilmesi amaçlanmıştır. Matematik dersi kapsamında öğrencilerin tüketim bilinci kazanmalarına yönelik herhangi bir öğrenme alanı ve konu bulunmamakla birlikte, bazı kazanımlar yoluyla bilinçli tüketici rollerinin geliştirilmesi amaçlanmıştır. İlkokul 4. sınıf öğretim programları incelendiğinde ise bilinçli tüketim ile ilgili en kapsamlı içeriğe sahip dersin Sosyal Bilgiler dersi olduğu görülmektedir. Gerek programın amaçlarında gerekse program kapsamında kazandırılması düşünülen beceri ve değer ifadelerinde tüketimle ilgili kavramların yer aldığı görülmektedir. Ayrıca, Sosyal Bilgiler dersinde Üretim, Dağıtım ve Tüketim öğrenme alanı ile öğrencilerin üretim, dağıtım ve tüketimle ilgili temel kavramları öğrenmesi, istek ve ihtiyaçları arasında fark olduğunu ayırt ederek insanoğlunun sınırsız istekleri karşısında kaynakların sınırlı olduğunun bilincine varması amaçlanmıştır (MEB, 2005;
MEB, 2009a; MEB, 2009b; MEB, 2009c; MEB, 2012; MEB, 2013).

Alan yazındaki çalışmalar incelendiğinde öğrencilere verilen tüketici eğitiminin öğrencilerin tüketime yönelik bilgi ve bilinç düzeyleri üzerinde olumlu etkide bulunduğu ifade edilmektedir (Ersoy, 2005; P1narc1, 2007; Ünay, 2012). Bununla birlikte, öğrencilerin tüketim davranışlarının ve tüketime yönelik bilgi ve bilinç düzeylerinin yetersizliğine vurgu yapan çalışmalara rastlanmaktadır (Kahyaoğlu ve Kırıktaş, 2010; Purutçuoğlu, 2003; Sert, 2002; Varcoe, \& arkadaşları, 2001). Ayrıca, ilkokullarda uygulanmakta olan öğretim programlarının tüketici eğitimi bakımından eksikliğine dikkat çekilmektedir (Altık, 2010; Karaman Kepenekli ve Ökdem, 2013). Ülkemizde bilinçli tüketicilik konusuyla ilgili alan yazın incelendiğinde, bireylerin tüketicilik bilinci düzeylerini incelemeye yönelik uygulamaların daha çok ortaokul ve lise düzeyinde gerçekleştirildiği görülmektedir (Akyüz, 2009; Ersoy ve Nazik, 2006; Sert, 2002).

Çocukların tüketici davranışlarının gelişim süreci, tüketici sosyalleşmesi kavramı içinde ele alınmaktadır. Tüketici sosyalleşmesi, çocukların tüketici olarak pazarda sahip olmaları gereken bilgi, beceri ve tutumların ortaya çıkış süreci olarak tanımlanmaktadır (Ward, 1974). Çocukların tüketici olarak sosyalleşme süreçleri bireysel faktörlerin, sosyalleşme araçlarının ve öğrenme modellerinin etkileşimiyle şekillenen karmaşık bir süreci ifade etmektedir (Verma, \& Kapoor, 2004). Tüketim alışkanlıklarını doğrudan etkilemesi nedeniyle sosyoekonomik düzey, çocukların sosyalleşmelerini etkileyen bireysel faktörlerin başında gelmektedir (Ateşoğlu ve Türkkahraman, 2009). Alan yazın incelendiğinde sosyoekonomik düzeyin, çocukların tüketimle ilgili bilgi, beceri ve deneyim edinim süreçlerinin farklı aşamalarında doğrudan ve dolaylı bir biçimde etki ettiğini gösteren araştırmalarla karşılaşılmaktadır (Moschis, \& Churchill, 1978; Moschis, \& Moore, 1979; Nazik ve Şanlıer, 2001; Özgen, 1995; Riesman, Glaser, \& Denny, 1950; Ward, 1974).

Etnik, ekonomik, kültürel vb. nedenlerle bölgeler, şehirler ve hatta aynı il sınırları içinde bulunan yerleşim yerleri arasındaki sosyoekonomik farklılıkların oldukça belirgin olduğu ülkemizde, çocukların tüketici davranışlarının bu çerçevede değerlendirilmesi önemli görülmektedir. $\mathrm{Bu}$ nedenlerle bilinçli tüketicilik konusunda kapsamlı çalışmalara ihtiyaç duyulduğundan, ilkokul 4. sınıf öğrencilerinin bilinçli tüketicilik durumlarının sosyoekonomik çevre değişkenine göre belirlenerek uygulanmakta olan ilkokul programlarının bilinçli tüketici davranışları kazandırma ve geliştirmede ne derece etkili olduğunun ortaya konulmasının alana katkı getireceği düşünülmektedir. Bununla birlikte bu araştırma; farklı sosyoekonomik çevrelerdeki okullarda öğrenim gören ilkokul 4. sınıf öğrencilerinin bilinçli tüketicilik düzeylerini belirlemek, tüketici eğitimi bakımından uygulanmakta olan ilkokul 4. sınıf öğretim programlarının geliştirilmesine yönelik çalışmalara katkı sağlamak ve programların uygulayıcıları olarak öğretmenlere programların niteliği hakkında bir bakış açısı kazandırması bakımından önemli görülmektedir. Ayrıca gerçekleştirilen çalışmanın bir karma yöntem araştırması olması, gerek problemi çok yönlü ele alması gerekse elde edilen nicel bulguları nitel bulgularla 
desteklemesi bakımından alan yazına katkı sağlayacağı düşünülmektedir.

$\mathrm{Bu}$ araştırmanın genel amacı, ilkokul 4. sınıf öğrencilerinin bilinçli tüketicilik durumlarını incelemektir. Bu genel amaç doğrultusunda şu sorulara yanıt aranmıştır:

1. Öğrencilerin bilinçli tüketicilik düzeyleri; Cinsiyet,

Ailenin sosyoekonomik düzeyi,

Okulun bulunduğu sosyoekonomik çevre,

Anne ve babanın eğitim düzeyi,

Anne ve babanın mesleği,

Öğrencinin haftalık harçlık miktarı,

- Öğrencinin harçlık birikim miktarı değişkenleri bakımından anlamlı farklılık göstermekte midir?

2. Öğrencilerin;

- Bilinçli tüketiciliğe,

- Bilinçli tüketicinin sergilemesi gereken davranışlara,

- Kendilerine yönelik bilinçli tüketicilik algılarına,

- Tüketici olarak sahip oldukları haklara ilişkin görüşleri nelerdir?

$\mathrm{Bu}$ araştırma, 2014-2015 eğitim-öğretim y1lında Eskişehir'de Milli Eğitim Müdürlüğü'ne bağlı ilkokulların 4. sınıflarında öğrenim gören ve araştırmaya katılan öğrencilerin görüşleri ile sınırlıdır.

\section{Yöntem ve Uygulama}

$\mathrm{Bu}$ bölümde araştırmanın modeli, çalışma grubu, veri toplama araçları, verilerin toplanması ve verilerin analizi başlıkları altında araştırmanın yöntem kısmında gerçekleştirilen çalışmalara yer verilmiştir.

\subsection{Araştırma Modeli}

Araştırma, karma yöntem araştırma modeliyle desenlenmiştir. Karma yöntem araştırma modeli, nitel ve nicel araştırma yaklaşımlarının tek bir çalışma içerisinde bir arada kullanıldığı araştırma tasarımıdır (Creswell, 1999; Johnson, \& Onwuegbuzie, 2004). Alan yazında karma yöntem araştırmalarıyla ilgili birçok tasarım yer almaktadır (Creswell, 2003; Johnson, \& Onwuegbuzie, 2004; Leech, \& Onwuegbuzie, 2009; Morse, 1991; Morse, 2003). Bu çalışma kapsamında Leech ve Onwuegbuzie (2009) tarafından önerilen karma yöntem modelinin kısmen karma sıralı baskın tasarımı benimsenmiştir. $\mathrm{Bu}$ tasarım nitel ve nicel olmak üzere iki aşamadan oluşan, her bir aşamanın sıralı olarak uygulandığı ve nitel ya da nicel bileşenlerden birinin daha baskın olduğu bir karma yöntem tasarımıdır (Leech, \& Onwuegbuzie, 2009). Bu çalışmada, nitel veriler nicel verileri açıklama amacıyla toplandığından araştırmanın nitel boyutu nicel boyutuna göre daha baskındır. Araştırmanın nicel boyutu ilişkisel tarama, nitel boyutu ise olgu bilim çalışması biçiminde desenlenmiştir. Araştırmanın nicel boyutunda bilinçli tüketicilik düzeyi ölçeği ile nicel veriler, nitel boyutunda ise yarı yapılandırılmış görüşme formu aracılığıyla nitel veriler elde edilmiştir. Yarı yapılandırılmış görüşmeler sonucu ulaşılan nitel bulgularla, bilinçli tüketicilik düzeyi ölçeği ile elde edilen nicel bulgular desteklenmeye çalışılmıştır.

\section{2. Çalışma Grubu}

Karma yöntem araştırmalarında dört temel örneklem belirleme kategorisi bulunmaktadır. Araştırma kapsamında sıralı karma yöntem örneklemi kullanılmıştır. Bu örneklem belirleme yaklaşımı, nitel-nicel ya da nicel-nitel yöntemlerin sıralı olarak uygulandığı ve ilk aşamada uygulanan yöntemin bir sonraki aşamada uygulanacak yöntemde kullanılacak örneklemi belirlediği yaklaşımdır (Teddlie, \& Yu, 2007).

Araştırmanın evrenini 2014-2015 eğitim-öğretim yılında Eskişehir ili Odunpazarı ve Tepebaşı ilçelerindeki ilkokullarda öğrenim gören 4. sınıf öğrencileri oluşturmaktadır. Araştırmanın örneklemi araştırma evreni içinden, okulların bulunduğu alt, orta ve üst sosyoekonomik çevreler dikkate alınarak tabakalı örnekleme yöntemiyle belirlemiştir (Yıldırım ve Şimşek, 2011). Bu bağlamda araştırmanın çalışma evrenini alt, orta ve üst olarak tabakalara ayrılan sosyoekonomik çevrelerden seçilen 15 ilkokulun 4. sınıf öğrencileri oluşturmaktadır. Araştırmanın ilişkisel tarama biçiminde desenlenen nicel aşamasında toplam 478 öğrenciye ulaşılmıştır. $\mathrm{Bu}$ öğrencilere ilişkin demografik bilgiler Tablo 1'de gösterilmiştir.

Tablo 1. Araştırmaya katılan öğrencilere ilişkin demografik bilgiler

\begin{tabular}{|c|c|c|c|}
\hline Değişken & & $f$ & $\%$ \\
\hline \multirow[t]{2}{*}{ Cinsiyet } & $\mathrm{K} 1 \mathrm{Z}$ & 227 & 47,5 \\
\hline & Erkek & 251 & 52,5 \\
\hline \multirow{4}{*}{$\begin{array}{l}\text { Anne Eğitim } \\
\text { Düzeyi }\end{array}$} & Okuma-yazma bilmiyor & 13 & 2,7 \\
\hline & İlköğretim mezunu & 195 & 40,8 \\
\hline & Ortaöğretim mezunu & 195 & 40,8 \\
\hline & Yükseköğretim mezunu & 75 & 15,7 \\
\hline \multirow{3}{*}{$\begin{array}{l}\text { Baba Eğitim } \\
\text { Düzeyi }\end{array}$} & İlköğretim mezunu & 52 & 10,9 \\
\hline & Ortaöğretim mezunu & 258 & 54,0 \\
\hline & Yükseköğretim mezunu & 168 & 35,1 \\
\hline \multirow{3}{*}{$\begin{array}{l}\text { Ailenin Aylık } \\
\text { Geliri }\end{array}$} & TL $0-2000$ & 154 & 32,2 \\
\hline & TL 2001-4000 & 258 & 54,0 \\
\hline & TL 4001 ve üzeri & 168 & 35,1 \\
\hline \multirow{4}{*}{$\begin{array}{l}\text { Annenin } \\
\text { Mesleği }\end{array}$} & Çalışmıyor & 317 & 66,3 \\
\hline & Devlet memuru & 55 & 11,5 \\
\hline & Özel sektör & 43 & 9,0 \\
\hline & Serbest meslek & 63 & 13,2 \\
\hline \multirow{4}{*}{$\begin{array}{l}\text { Babanın } \\
\text { Mesleği }\end{array}$} & Çalışmıyor & 5 & 1,0 \\
\hline & Devlet memuru & 117 & 24,5 \\
\hline & Özel sektör & 148 & 31,0 \\
\hline & Serbest meslek & 208 & 43,5 \\
\hline \multirow{4}{*}{$\begin{array}{l}\text { Ailedeki Birey } \\
\text { Say1s1 }\end{array}$} & 2 & 3 & 0,6 \\
\hline & 3 & 68 & 14,2 \\
\hline & 4 & 286 & 59,8 \\
\hline & $5+$ & 121 & 25,3 \\
\hline
\end{tabular}

Araştırmanın olgu bilim çalışması olarak desenlenen nitel aşamasında katılımcıların belirlenmesinde amaçlı örnekleme yöntemlerinden ölçüt örnekleme kullanılmıştır (Yıldırım ve Şimşek, 2011). Ölçüt olarak öncelikle her sosyoekonomik düzeyde nicel veri toplama aracından en yüksek puanı alan okulların belirlenmesine ardından bu okullarda araştırmaya katılan öğrenciler arasından yine nicel veri toplama aracından en yüksek puanı alan öğrencilerin seçilmesine karar verilmiştir. Buradaki amaç yarı yapılandırılmış görüşmelerin gerçekleştirileceği öğrencilerden zengin düzeyde verilerin elde edilmek istenmesidir. Ölçek puanı yüksek öğrencilerden daha zengin veriler elde edileceği düşünülerek yarı 
yapılandırılmış görülmeler nicel veri toplama aracından en yüksek puanı alan öğrencilerle gerçekleştirilmiştir. Belirlenen ölçüt doğrultusunda alt, orta ve üst sosyoekonomik çevreleri temsilen 15 öğrenci araştırmanın nitel aşamasına dahil edilmiştir. $\mathrm{Bu}$ öğrencilere ilişkin bilgiler Tablo 2'de gösterilmiştir.

Tablo 2. Görüşmeye Katılan Öğrencilere İlişkin Bilgiler

\begin{tabular}{|c|c|c|c|c|}
\hline $\begin{array}{l}\text { Sosyoekonomik } \\
\text { Çevre }\end{array}$ & $\begin{array}{l}\text { Öğrencinin } \\
\mathrm{Ad1}^{\mathrm{a}}\end{array}$ & Cinsiyet & Yaş & $\begin{array}{l}\text { BTDÖ } \\
\text { Puanı } \\
\end{array}$ \\
\hline \multirow[t]{5}{*}{ Alt } & Arda & Erkek & 11 & 73 \\
\hline & İclal & $\mathrm{K}_{1 \mathrm{Z}}$ & 10 & 72 \\
\hline & Talha & Erkek & 10 & 72 \\
\hline & Efe & Erkek & 10 & 71 \\
\hline & Esma & $\mathrm{K} 1 \mathrm{z}$ & 10 & 70 \\
\hline \multirow{5}{*}{ Orta } & Mustafa & Erkek & 10 & 74 \\
\hline & Melike & $\mathrm{K}_{1 \mathrm{Z}}$ & 11 & 72 \\
\hline & Erol & Erkek & 10 & 70 \\
\hline & Zeynep & $\mathrm{K}_{1 \mathrm{Z}}$ & 10 & 70 \\
\hline & Yusuf & Erkek & 10 & 69 \\
\hline \multirow[t]{5}{*}{ Üst } & Çağatay & Erkek & 11 & 76 \\
\hline & Emre & Erkek & 10 & 74 \\
\hline & Serhat & Erkek & 10 & 73 \\
\hline & Azra & $\mathrm{K}_{1 \mathrm{Z}}$ & 10 & 73 \\
\hline & Nur & K1z & 10 & 73 \\
\hline
\end{tabular}

${ }^{a}$ Öğrencilerin isimlerinin gizli tutulması için kod isimler kullanılmıştır.

\subsection{Veri Toplama Araçları}

Araştırmada nitel ve nicel veri toplama yöntemleri bir arada kullanılmıştır. Araştırmanın nicel verileri Sağlam (2010a) tarafından geliştirilen Bilinçli Tüketicilik Düzeyi Ölçeği, nitel verileri ise yarı yapılandırılmış görüşme formu aracılığı ile elde edilmiştir. Araştırma kapsamında ayrıca öğrencilere ilişkin demografik bilgilerin elde edilmesi amacıyla kişisel bilgi formu kullanılmıştır.

Bilinçli tüketicilik düzeyi ölçeği: Araştırmanın nicel boyutunda Sağlam (2010a) tarafindan geliştirilen ve 19 maddeden oluşan Bilinçli Tüketicilik Düzeyi Ölçeği (BDTÖ) kullanılmıştır. Ölçekten elde edilebilecek en yüksek puan 76 en düşük puan 19'dur. Bilinçli tüketicilik düzeylerinin belirlenmesinde ölçekten elde edilen toplam puanın ölçeği oluşturan madde sayısına bölümü ile elde edilen ortalamadan yararlanılmaktadır. Buna göre öğrencilerin bilinçli tüketicilik düzeyleri, ölçekten elde ettikleri madde ortalama puanlarına göre 1,00-1,75 aras1 için hiçbir zaman, 1,76-2,50 arası için ara sıra, 2,51-3,25 arası için çoğu zaman ve 3,26-4,00 arası için her zaman biçiminde değerlendirilmektedir (Sağlam, 2010a). Ölçeğin yap1 geçerliğini sağlamak için LISREL 8.70 programı kullanılarak doğrulayıcı faktör analizi uygulanmıştır. Doğrulayıcı faktör analizi sonucunda ölçeğe ilişkin bütün maddelerin .01 düzeyinde anlamlı $\mathrm{t}$ değeri verdiği belirlenmiştir. Ölçek maddelerinin iç tutarlık katsayısını belirlemek için hesaplanan Cronbach'ın $\alpha$ korelasyon katsayıs1 0.77 olarak bulunmuştur. Ölçeğin özgün formunun tamamına ilişkin güvenirlik katsayısı 0.77 olarak hesaplanmıştır (Sağlam, 2010a). Bu nedenle hesaplanan güvenirlik katsayısının alan yazında belirtilen aralığa çok yakın olduğu ve ölçeğin ideal güvenirlik değerine sahip olduğu kabul edilmiştir.

Yarı yapılandırılmış görüşme formu: Çalışmanın nitel boyutunda veri toplama aracı olarak kullanılmak üzere yarıyapılandırılmış görüşme formu geliştirilmiştir. Görüşme formu geliştirilirken öncelikle bir taslak form hazırlanmıştır. Hazırlanan formda yer alan soruların belirlenmesinde araştırmanın amacı ve alan yazında yer alan çalışma bulguları dikkate alınmıştır. Hazırlanan taslak form araştırma örneklemine benzer örneklem grubu üzerinde uygulanmış ve soruların anlaşılırlığının kontrol edilmesi sağlanmıştır. Geri dönütler doğrultusunda yarı yapılandırılmış görüşme formuna son şekli verilmiştir. Yarı-Yapılandırılmış Görüşme Formu öğrencilerin bilinçli tüketiciliğe, bilinçli bir tüketicinin sergilemesi gereken davranışlara, kendilerine yönelik tüketicilik algılarına ve tüketici olarak sahip oldukları haklara ilişkin görüşlerini belirlemek amacıyla hazırlanmış sorulardan oluşmaktadır.

Kişisel bilgi formu: Öğrenci kişisel bilgi formu araştırmaya katılan öğrencilere ilişkin bilgi edinmek amacıyla kullanılmıştır. Formun içeriğini öğrencinin cinsiyet, anne ve baba eğitim durumu, aile aylık gelir durumu, ailedeki birey sayısı, anne ve baba çalışma durumu, haftalık harçlık miktarı ve harçlık biriktirme durumu değişkenlerine ilişkin maddeler oluşturmaktadır. Söz konusu değişken maddelerinin belirlenmesinde araştırmanın amacı ve alan yazında yer alan çalışma bulguları dikkate alınmıştır.

\subsection{Verilerin Toplanmas1}

Araştırma verilerinin toplanmaya başlanmasından önce ilk olarak araştırma kapsamında uygulanması planlanan ölçeğe ilişkin gerekli izinler alınmıştır. Ayrıca ölçek, kişisel bilgi formu ve yarı yapılandırılmış görüşme formunun okullarda uygulanması için de Eskişehir İl Milli Eğitim Müdürlüğünden gerekli izinler alınmıştır. Araştırmada ilk olarak belirlenen okullarda 4. sınıf öğrencilerine Kişisel bilgi formları ve BTDÖ uygulanmıştır. 15 ilkokuldan toplam 478 öğrenciye ulaşılmıştır. Veri toplama sürecinin ikinci aşamasında öğrencilere uygulanmak üzere araştırmacı tarafından geliştirilen yarı yapılandırılmış görüşme formu kullanılmıştır. Görüşmeler için ilgili okulların rehberlik odalarında gerçekleştirilmiştir. Gönüllülük esasına dayalı olarak gerçekleştirilen görüşmeler için gerek öğrencilerden gerekse sınıf öğretmenlerinden gerekli izinler alınmıştır. Görüşmeler bizzat araştırmacı tarafından gerçekleştirilmiş, görüşmelerde okul rehber öğretmeni de görüşmenin gerçekleştirildiği ortamda yer almıştır. Görüşmeler ses kayıt cihazı ile kayıt altına alınmıştır.

\subsection{Verilerin Analizi}

Araştırmanın nicel verilerinin çözümlenmesinde öncelikle parametrik testlerin uygulanabilmesi için gerekli şartlar test edilmiştir. Bu noktada öncelikle bakılması gereken ölçüt, örneklem büyüklüğüdür. Örneklem büyüklüğünün 30'dan az olması parametrik olmayan yöntemlerin kullanılmasını gerektirir (Baykul ve Adıgüzel, 2013). Bu çalışmada örneklem büyüklüğünün 478 olması parametrik testlerin kullanılması için gerekli şartlardan ilkinin sağlandığını göstermektedir. Ancak parametrik testlerin kullanılabilmesi için verilerin normal dağılması ve varyansların homojenliği gerekmektedir. Bağımlı değişkenlere ait ölçümlerin normal dağılım varsayımını test ederken bu amaç için kullanılan Kolmogorov-Simirnov istatistiği ile veriler analiz edilmiştir. Tek Örneklem Kolmogorov-Simirnov Testi sonucuna göre dağılımın normal olmadığı görülmüştür, $\mathrm{D}(478)=0,108, \mathrm{p}<.05$. Ayrıca verilere ait basıklık $(1,405)$ ve 
çarpıklık $(-1,075)$ değerlerinin kabul edilebilir değerler olan “-1, +1" değer aralığının dışında olduğu görülmektedir (Huck, 2008). Bu nedenler göz önünde bulundurulduğunda verilerin analizinde parametrik olmayan istatistiklerden yararlanılmasına karar verilmiştir. Buna göre, araştırmanın nicel verileri çözümlenirken, gruplar arası karşılaştırmalarda Mann Whitney U ve Kruskal Wallis H testlerinden yararlanılmıştır. İstatistiksel olarak anlamlı fark bulunan gruplarda etki büyüklüğü değerine ulaşmak için Cohen'in d değeri hesaplanmıştır. Yapılan analiz sonuçlarının yorumlanmasında anlamlılık düzeyi 0.05 olarak kabul edilmiştir. Ölçek verilerinin bilgisayar ortamına aktarılmasında ve istatistiksel hesaplamaların yapılmasında SPSS programından yararlanılmıştır.

Araştırma kapsamında elde edilen nitel veriler tematik analiz yöntemi kullanılarak çözümlenmiştir (Liamputtong, 2009). Yarı-yapılandırılmış görüşme formu aracılığıyla öğrencilerle gerçekleştirilen ve kayıt altına alınan görüşmeler hiçbir değişikliğe uğramadan yazılı olarak bilgisayar ortamına aktarılmıştır. Veri dökümlerinin tutarlılığını değerlendirmek amacıyla bir uzmanla çalışılmıştır. Seçilen temsili döküm ve kayıtların arasında tutarlılığın sağlandığının tespit edilmesinin ardından görüşme dökümlerinin kodlama anahtarı aracılığıyla belirlenen temalara uygun olarak kodlanması gerçekleştirilmiştir. Bu aşamada da bir uzmandan yardım alınarak bağımsız kodlayıcılar arasındaki tutarlılığın sağlanması amaçlanmıştır. Bu işlem esnasında görüşme formlarının \%20-25'ine karşıllk gelen 3 form yansız atama ile belirlenmiştir (Gay, 1987). Bu formlar araştırmacı ve uzman tarafından birbirinden bağımsız olarak kodlanmıştır. Görüşme formu toplam 4 sorudan oluşmaktadır. Her bir soru kapsamında araştırmacı ve uzman arasında belirlenen kodlara ilişkin görüş birliği ve görüş ayrılığı sayısı Tablo 3 'te gösterilmiştir.

Tablo 3. Görüşme Sorularına Yönelik Görüş Birliğine Varılan ve Varılmayan Kod Sayıları ve Güvenirlik Yüzdeleri

\begin{tabular}{lccc}
\hline Soru & $\begin{array}{c}\text { Görüş birliği } \\
\text { sağlanan kod }\end{array}$ & $\begin{array}{c}\text { Görüş ayrılığına } \\
\text { varılan kod }\end{array}$ & $\begin{array}{c}\text { Güvenirlik } \\
(\%)\end{array}$ \\
\hline 1 & 14 & 3 & 82 \\
2 & 29 & 2 & 94 \\
3 & 28 & 2 & 93 \\
4 & 3 & 0 & 100 \\
\hline
\end{tabular}

Analiz işleminin tamamlanmasının ardından araştırmacı ve bağımsız kodlayıcı Miles ve Huberman'ın (1994) uyuşum yüzdesi formülünü uygulamışlardır. $\mathrm{Bu}$ formüle göre güvenirlik, üzerinde görüş birliğine varılan kod sayısının üzerinde görüş birliğine varılan ve varılmayan kod sayılarının toplamına oranı üzerinden hesaplanmaktadır. Burada amaç, üzerinde görüş birliği sağlanan terim sayısı ve üzerinde görüş birliği sağlanmayan terim sayısının birbirine oranı üzerinden iç tutarlılığın sağlanıp sağlanmadığının belirlenerek nitel araştırmanın güvenirliğini ortaya koymaktır. Yapılan hesaplamalara göre her bir soru için öncelikle ayrı ayrı hesaplanan güvenirlik katsayısı ardından görüşme formu geneli için \%92,25 olarak hesaplanmıştır. Kodlayıcılar arası görüş birliğinin en az \%80 olması gerektiğinden hareketle değerlendirmeler aras1 güvenirliğin sağlandığ1 görülmektedir (Gay, 1987; Miles, \& Huberman, 1994). Görüşme kodlama anahtarına göre işlenmiş olan veriler araştırma soruları çerçevesinde ilgili yerlerde doğrudan alıntılarla ve karma yöntemin doğasına uygun olarak elde edilen nicel bulgularla desteklenerek tanımlanmış, tanımlanan bulgular açıklanarak ilişkilendirilmiş ve anlamlandırılarak yorumlanmıştır.

\section{Bulgular}

Bulguların ele alınmasında araştırmaya temel oluşturan karma model dikkate alınmıştır. Araştırmanın nicel verilerine ilişkin istatistiksel bulgular tablolarla betimlenerek yorumlanmıştır. Araştırma kapsamında elde edilen nitel verilerin tematik analizleri yapılarak oluşturulan temalar araştırmanın alt problemleriyle ilişkilendirilmiş ve ulaşılan bulgular çerçevesinde yorumlanmıştır.

\section{1. Öğrencilerin BTDÖ’nden Elde Ettikleri Puanların Bazı Değişkenler Bakımından İncelenmesi}

Öğrencilerinin BTDÖ puanlarının cinsiyete göre MannWhitney-U testi sonuçları Tablo 4'te gösterilmiştir.

Tablo 4. BTDÖ Puanlarının Cinsiyete Göre Mann-Whitney-U Testi Sonuçları

\begin{tabular}{lccccc}
\hline Cinsiyet & N & $X$ & Sira Ort. & U & P \\
\hline K1z & 227 & 3,35 & 245,07 & 27223,50 & .401 \\
Erkek & 251 & 3,34 & 234,46 & & \\
\hline
\end{tabular}

Tablo 4 incelendiğinde, ilkokul 4. sınıf öğrencilerinin bilinçli tüketicilik düzeylerinin cinsiyetlerine göre ölçekten elde edilen toplam puanlar dikkate alındığında anlamlı bir biçimde farklılaşmadığı görülmektedir, $U=27223.50$, $p>0.05$. Ölçek toplamına göre hem kız hem de erkek öğrencilerin bilinçli tüketicilik durumlarının yüksek düzeyde tüketim bilincini ifade eden her zaman düzeyinde olduğu belirlenmiştir.

Öğrencilerin BTDÖ puanlarının okulun bulunduğu sosyoekonomik çevre değişkenine göre Kruskal Wallis-H testi sonuçları Tablo 5 'te gösterilmiştir.

Tablo 5. BTDÖ Puanlarının Okulun Bulunduğu Sosyoekonomik Çevreye Göre Kuruskal Wallis-H Testi Sonuçları

\begin{tabular}{lcccccc}
\hline Düzey & $\mathrm{N}$ & $X$ & Sira O. & $X$ & $\mathrm{p}$ & Fark \\
\hline Alt (1) & 149 & 3,20 & 188,59 & 31.207 & .000 & $1-2$ \\
Orta (2) & 163 & 3,40 & 252,47 & & & $1-3$ \\
Üst (3) & 166 & 3,43 & 272,46 & & & \\
\hline *p $<.05$ & & & & & &
\end{tabular}

Tablo 5'teki analiz sonuçları, ilkokul 4. sınıf öğrencilerinin bilinçli tüketicilik düzeylerinin okulun bulunduğu sosyoekonomik çevreye göre ölçekten elde edilen toplam puanlar bakımından anlamlı bir biçimde farklılaştığını göstermektedir, $H(2)=31,207, \mathrm{p}<0.05$. Ölçekten elde edilen toplam puanlar ele alındığında, üst ve orta sosyoekonomik çevredeki ilkokullarda öğrenim gören öğrencilerin, alt sosyoekonomik çevredeki ilkokullarda öğrenim gören öğrencilere göre daha bilinçli oldukları görülmektedir. Alt sosyoekonomik çevredeki okullarda öğrenim gören öğrencilerin tüketim bilinçleri çoğu zaman düzeyindeyken, orta ve üst sosyoekonomik çevredeki okullarda öğrenim gören öğrencilerin tüketim bilinçleri her zaman düzeyindedir. $\mathrm{Bu}$ durum okulun bulunduğu çevrenin sosyoekonomik düzeyi arttıkça öğrencilerin bilinçli tüketicilik düzeylerinin de arttığı biçiminde yorumlanabilir. 
Öğrencilerin BTDÖ puanlarının annenin ve babanın eğitim durumu, ailenin aylık gelir durumu, anne ve babanın mesleki durumu, öğrencinin haftalık harçlık miktarı ve öğrencilerin harçlıklarını biriktirme durumu değişkenlerine göre Kruskal Wallis-H testi sonuçları Tablo 6'da gösterilmiştir.

Tablo 6. Grupsal Ana Faktörü Altındaki Alt Faktörlerin Nihai İkili Karşılaştırmaları ve Faktör Ağırlıkları

\begin{tabular}{|c|c|c|c|c|c|c|c|}
\hline Değişken & & $\mathbf{N}$ & Sira ort. (SO) & Sd & $\chi^{2}$ & $\mathbf{p}$ & Anlamlı fark \\
\hline \multirow{10}{*}{$\begin{array}{l}\text { Eğitim } \\
\text { Durumu }\end{array}$} & Anne ĕgitim durumu & & & & & & \\
\hline & Okuma-yazma bilmiyor (1) & 13 & 98,46 & 3 & 28,099 & $.000 *$ & $1-2$ \\
\hline & İlköğretim mezunu (2) & 195 & 230,30 & & & & $1-3$ \\
\hline & Ortaöğretim mezunu (3) & 195 & 235,60 & & & & $1-4$ \\
\hline & Yükseköğretim mezunu (4) & 75 & 298.01 & & & & $2-4$ \\
\hline & & 15 & & & & & $3-4$ \\
\hline & Babanın eğitim durumu & & & & & & \\
\hline & İlköğretim mezunu (1) & 52 & 194,45 & 2 & 19,329 & $.000 *$ & $1-3$ \\
\hline & Ortaöğretim mezunu (2) & 258 & 225,47 & & & & $2-3$ \\
\hline & Yükseköğretim mezunu (3) & 168 & 274,99 & & & & \\
\hline \multirow{10}{*}{$\begin{array}{l}\text { Mesleki } \\
\text { Durum }\end{array}$} & Annenin mesleki durumu & & & & & & \\
\hline & Çalışmıyor (1) & 317 & 228,90 & 3 & 10,409 & $.015 *$ & \\
\hline & Devlet Memuru (2) & 55 & 293,05 & & & & $1-2$ \\
\hline & Özel Sektör (3) & 43 & 236,85 & & & & \\
\hline & Serbest Meslek (4) & 63 & 247,92 & & & & \\
\hline & Babanın mesleki durumu & & & & & & \\
\hline & Çalışmıyor (1) & 5 & 50,50 & 3 & 12,925 & $.005^{*}$ & $1-2$ \\
\hline & Devlet Memuru (2) & 117 & 261,75 & & & & $1-3$ \\
\hline & Özel Sektör (3) & 148 & 232,20 & & & & $1-4$ \\
\hline & Serbest Meslek (4) & 208 & 236,72 & & & & \\
\hline \multirow{3}{*}{ Gelir Durumu } & TL 0 - $2000(1)$ & 154 & 202,09 & 2 & 23,148 & $.000 *$ & $1-2$ \\
\hline & TL $2001-4000(2)$ & 258 & 247,44 & & & & $1-3$ \\
\hline & TL 4001 ve üzeri (3) & 66 & 295,75 & & & & $2-3$ \\
\hline \multirow{3}{*}{ Harçlık } & TL 1-10 & 413 & 235,48 & 2 & 5,264 & .072 & \\
\hline & TL 11-20 & 53 & 251,67 & & & & \\
\hline & TL 20 ve üzeri & 12 & 324,00 & & & & \\
\hline \multirow{5}{*}{ Birikim } & Harçlik biriktirmiyor (1) & 29 & 150,93 & 4 & 14,897 & $.005^{*}$ & \\
\hline & Tamamını (2) & 44 & 226,06 & & & & $1-3$ \\
\hline & Yarısından fazlasını (3) & 125 & 257,67 & & & & $1-4$ \\
\hline & Yarisinı (4) & 215 & 240,60 & & & & $1-5$ \\
\hline & Yarısından daha azını (5) & 65 & 249,54 & & & & \\
\hline
\end{tabular}

$* \mathrm{p}<.05$

Tablo 6'daki analiz sonuçları, ilkokul 4. sınıf öğrencilerinin bilinçli tüketicilik düzeylerinin annenin ve babanın eğitim durumuna göre ölçekten elde ettikleri toplam puanlar bakımından anlamlı bir biçimde farklılaştığını göstermektedir, $H(3)=28,099, \mathrm{p}<0.05 ; H(2)=19,329$, $\mathrm{p}<0.05$. Ölçek genelinde elde edilen toplam puanlar ele alındığında, annesi yükseköğretim, ortaöğretim ve ilköğretim mezunu olan öğrencilerin, annesi okuma-yazma bilmeyen öğrencilere göre; annesi yükseköğretim mezunu olan öğrencilerin, annesi ilköğretim ve ortaöğretim mezunu olan öğrencilere göre daha bilinçli oldukları görülmektedir. Babanın eğitim düzeyi bakımından ele alındığında, babası yükseköğretim mezunu olan öğrencilerin, babası ilköğretim ve ortaöğretim mezunu olan öğrencilere göre daha bilinçli oldukları görülmektedir. Ancak annenin eğitim durumu değişkeni içerisinde aleyhine anlamlı fark ortaya çıkan grubun frekans sayısı 13 olduğu düşünüldüğünde ortaya çıkan farkın grubun frekans sayısının azlığından kaynaklanmış olabileceği göz önüne alınmalıdır. Tarama araştırmalarında iki grup arası karşılaştırmaların yapılabilmesi için gruptaki birey sayısının minimum 30 olması gerekmektedir (Fraenkel, Wallen, \& Hyun, 2012). Bununla birlikte annenin eğitim durumu değişkeni hem ilkokul mezunu olma hem de ortaöğretim mezunu olma durumları karşısında yükseköğretim mezunu olma durumu lehine anlamlı farklılık ortaya çıkarmıştır. Bu kapsamda değerlendirildiğinde okuma-yazma bilmeme durumu karşısında yükseköğretim mezunu olma lehine anlamalı farklılık ortaya çıkabileceği kabul edilebilir. Sonuç olarak, yapılan analiz sonuçlarına göre annenin ve babanın eğitim düzeyi arttıkça öğrencilerin bilinçli tüketicilik düzeylerinin de arttığı görülmektedir. Özellikle annenin okuma-yazma bilmesinin, öğrencilerin bilinçli tüketicilik düzeyleri üzerinde olumlu etkide bulunduğu görülmektedir. Bu durum annenin ve babanın eğitimli olmasının çocukların bilinçli tüketicilik düzeylerinin de artmasını sağladığı biçiminde yorumlanabilir.

İlkokul 4. sınıf öğrencilerinin bilinçli tüketicilik düzeylerinin annenin ve babanın mesleki durumuna göre ölçekten elde ettikleri toplam puanlar bakımından anlamlı bir biçimde farklılaştığını göstermektedir, $H(3)=10,409$, $\mathrm{p}<0.05 ; H(3)=12,925, \mathrm{p}<0.05$. Ölçek genelinde elde edilen toplam puanlar ele alındığında, annesi devlet memuru olan öğrencilerin, annesi çalışmayan öğrencilere göre daha bilinçli oldukları görülmektedir. Babanın mesleki durumu bakımından ele alındığında ise, babası devlet memuru, özel sektör çalışanı ve serbest meslek çalışanı olan öğrencilerin, babası çalışmayan öğrencilere göre daha bilinçli oldukları görülmektedir. Ancak tarama araştırmalarında iki grup arası karşılaştırmaların yapılabilmesi için gruptaki birey sayısının minimum 30 olmasının gerekmesi (Fraenkel, Wallen, \& Hyun, 2012) ve aleyhine anlamlı fark ortaya çıkan grubun frekans sayısı 5 olduğu düşünüldügüünde, ortaya çıkan 
farkın grubun frekans sayısının azlığından kaynaklanmış olabileceği göz önüne alınmalıdır. Bununla birlikte analiz sonuçlarına göre annesi devlet memuru olan öğrencilerin annesi çalışmayan öğrencilere göre bilinçli tüketicilik düzeylerinin daha yüksek olduğu görülmektedir. Benzer biçimde babanın iş sahibi olmasının da çocukların bilinçli tüketicilik düzeyleri üzerinde etkili olduğunu ortaya koyması bakımından elde edilen bulgular önemli görülmektedir. Bütün bu etkenler dikkate alındığında, annenin ve babanın çalışıyor olma durumunun çalışmayan annelere ve babalara göre çocukların bilinçli tüketicilik düzeylerini daha olumlu etkileyerek bilinçli tüketicilik düzeylerinin artmasını sağladığı biçiminde yorumlanabilir.

İlkokul 4. sınıf öğrencilerinin bilinçli tüketicilik düzeylerinin ailenin aylık gelir durumuna göre ölçekten elde ettikleri toplam puanlar bakımından anlamlı bir biçimde farklılaştığını göstermektedir, $H(2)=23,148$, $\mathrm{p}<0.05$. Ölçek genelinde elde edilen toplam puanlar ele alındığında, ailesinin aylık geliri 4001 TL'nin üzerinde olan öğrencilerin ailesinin aylık geliri 2001-4000 TL ve 0-2000 TL olan öğrencilere göre daha bilinçli oldukları belirlenmiştir. Benzer şekilde ailesinin aylık geliri 20014000 TL olan öğrencilerin, ailesinin aylık geliri 0-2001 TL olan öğrencilere göre daha bilinçli oldukları görülmektedir. Yapılan analiz sonuçlarına göre ailenin aylık gelir düzeyi arttıkça öğrencilerin bilinçli tüketicilik düzeylerinin de

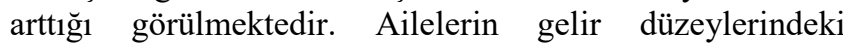
farklılıklar çocukların harcama alışkanlıkları ile istek ve ihtiyaçlarını karşılama durumları üzerinde etkili bir faktör olabilir. Bir diğer ifadeyle aylık gelir düzeyi düşük ailelerin içinde bulundukları ekonomik şartlar çocukların tüketim alışkanlıklarını biçimlendirmiş olabilir.

Tablo 6'daki analiz sonuçları, ilkokul 4. sınıf öğrencilerinin bilinçli tüketicilik düzeylerinin haftalık harçlık miktarına göre ölçekten elde ettikleri toplam puanlar bakımından anlamlı bir biçimde farklılaşmadığını göstermektedir, $H(2)$ $=5,264, \mathrm{p}>0.05$. Bu durum haftalık harçlık miktarının çocukların bilinçli tüketicilik düzeyleri üzerinde etkili bir rol oynamadığ 1 biçiminde yorumlanabilir.

Analiz sonuçları, ilkokul 4. sınıf öğrencilerinin bilinçli tüketicilik düzeylerinin harçlık biriktirme durumuna göre ölçekten elde ettikleri toplam puanlar bakımından anlamlı bir biçimde farklılaştığını göstermektedir, $H(4)=14,897$, $\mathrm{p}<0.05$. Ölçek genelinde elde edilen toplam puanlar ele alındığında, haftalık harçlığının yarısından fazlasını, yarısını ve yarısından daha azını biriktiren öğrencilerin, harçlık biriktirmeyen öğrencilere göre daha bilinçli oldukları görülmektedir. Elde edilen bulgular 1şı̆̆ında, çeşitli oranlarda bile olsa haftalık harçlığını biriktiren öğrencilerin harçlıklarından hiç birikim yapmayan öğrencilere göre bilinçli tüketicilik düzeylerinin daha yüksek olduğu sonucuna ulaşılabilir. $\mathrm{Bu}$ durum bilinçli tüketicilik düzeyi yüksek olan öğrencilerin para biriktirme eğiliminde oldukları ya da para biriktirme eğiliminde olan öğrencilerin para biriktiremeyen öğrencilere göre bilinçli tüketicilik düzeylerinin daha yüksek olduğu biçiminde yorumlanabilir.

\section{2. Öğrencilerin Bilinçli Tüketicilik Kavramına İlişkin Görüşleri}

Öğrencilerle gerçekleştirilen görüşmeler sonucunda öğrencilerin bilinçli tüketicilik kavramına ilişkin görüşleri dört tema etrafinda şekillenmiştir. Söz konusu temalar Şekil 1 'de gösteriliştir.

Şekil 1. Öğrencilerin Bilinçli Tüketiciliğe İlişsin Görüşleri

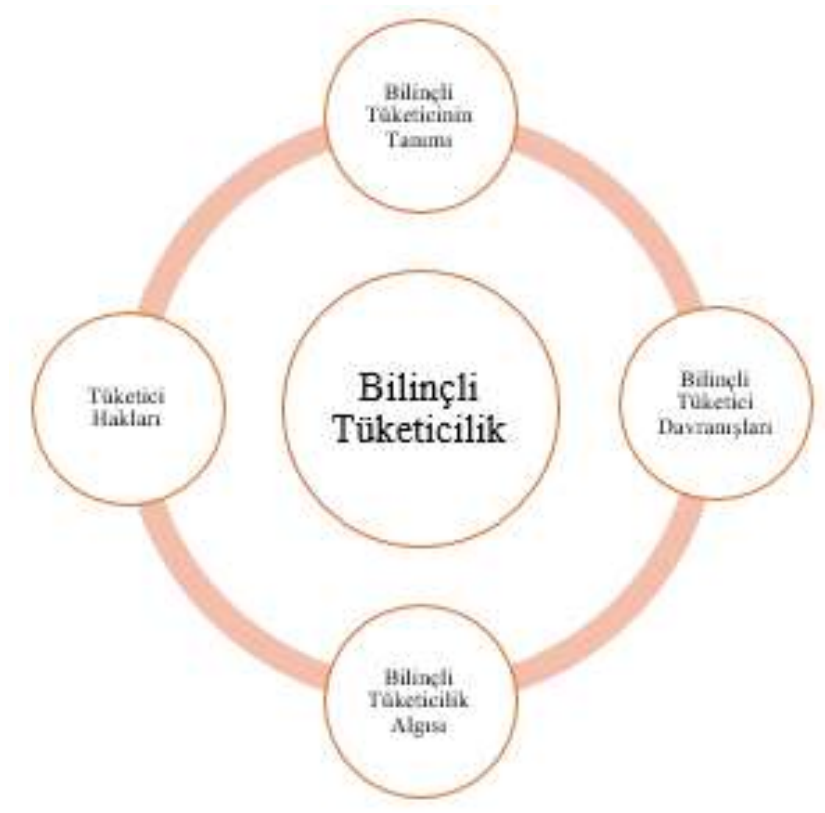

Öğrencilerin bilinçli tüketicilik kavramına ilişkin görüşleri "Bilinçli tüketicinin tanımı", "Bilinçli tüketici davranışları", "Bilinçli tüketicilik algısı" ve " Tüketici hakları" temaları çerçevesinde ele alınmıştır.

Öğrencilerin bilinçli tüketicinin tanımına ilişkin görüşleri üç alt tema çerçevesinde ele alınmıştır. Söz konusu alt temalar Şekil 2'de gösterilmiştir.

Şekil 2. Öğrencilerin Bilinçli Tüketicinin Tanımına İlişkin Görüşleri

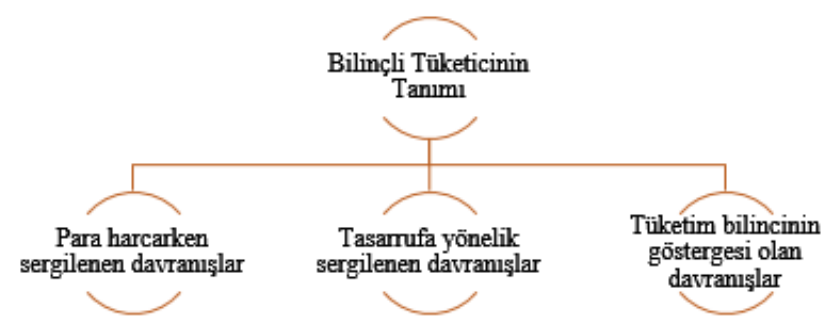

Şekil 2'de görüldüğü gibi, öğrencilerin bilinçli tüketicinin tanımına ilişkin görüşleri "Para harcarken sergilenen davranışlar", "Tasarrufa yönelik davranışlar" ve "Tüketim bilincinin göstergesi olan davranışlar" alt temaları içerisinde ele alınmıştır. Öğrenciler "Para harcarken sergilenen davranışlar" alt teması içerisinde bilinçli tüketici kavramı ile tüketicilerin harcama davranışlarına "Tasarrufa yönelik sergilenen davranışlar" alt teması içerisinde bilinçli tüketici kavramı ile tüketicilerin birikim, tasarruf ve tüketim alışkanlıklarına, "Tüketim bilincinin göstergesi olan davranışlar" alt teması içerisinde ise dolaylı olarak bilinçli tüketici kavramı ile ilişkilendirdikleri davranışlara değinmişlerdir. Gerçekleştirilen görüşmelerden elde edilen örnek cümleler aşağıdaki gibidir. 
"Öyle parasını falan çok aşmamalı. Ayağını yorganına göre uzatmalı. Tasarruf yapmalı. Eğer çok para harcarsan elinde para kalmaz. Bilinçli tüketici paralarını boşa harcamaz" (Efe).

"Bilinçli tüketici spor yapan kişidir. Bilinçli bir tüketicidir ama fazla yemek yemiş ve kilo almış, onları eritmek için spor yapabilir. Jimnastiğe başvurabilir. Sağlıklı yaşam için” (Nur)

Öğrencilerin bilinçli tüketicilik kavramının tanımı ile ilgili olarak belirttikleri görüşlerin okulun bulunduğu sosyoekonomik çevreye göre çeşitlilik gösterdiği belirlenmiştir. Söz konusu bulguya ilişkin bilgiler Tablo 7'de gösterilmiştir.

Tablo 7. Öğrencilerin Bilinçli Tüketicinin Tanımına İlişkin Görüşlerinin Okulun Bulunduğu Sosyoekonomik Çevreye Göre Dağılımı

\begin{tabular}{lccc}
\hline & Alt & Orta & Üst \\
\hline Para harcarken sergilenen davranışlar & & & \\
$\quad$ İhtiyaçlarına öncelik veren kişi & $\checkmark$ & $\checkmark$ & $\checkmark$ \\
Kaliteli ürünleri tercih eden kişi & & & $\checkmark$ \\
\hline Tasarrufa yönelik sergilenen davranışlar & & & \\
$\quad$ Parasını boşa harcamayan kişi & $\checkmark$ & $\checkmark$ & $\checkmark$ \\
İsraf etmeyen kişi & $\checkmark$ & $\checkmark$ & $\checkmark$ \\
Kaynakları boşa harcamayan kişi & & $\checkmark$ & $\checkmark$ \\
Para biriktiren kişi & & $\checkmark$ & $\checkmark$ \\
Ortalama tüketen kişi & & $\checkmark$ & \\
Tüketmeyi iyi bilen kişi & & $\checkmark$ & \\
Planlı hareket eden kişi & & & $\checkmark$ \\
Yetinen kişi & & $\checkmark$ & \\
\hline Tüketim bilincinin göstergesi olan davranışlar & & & \\
Sağlıklı beslenen kişi & $\checkmark$ & $\checkmark$ & $\checkmark$ \\
Spor yapan kişi & $\checkmark$ & & $\checkmark$ \\
Çevreyi koruyan kişi & & & $\checkmark$ \\
Haklarını koruyan kişi & & $\checkmark$ & $\checkmark$ \\
\hline
\end{tabular}

Tablodaki bilgiler 1şı̆̆ında alt sosyoekonomik çevredeki ilkokulda öğrenim gören öğrencilerin bilinçli tüketicilik kavramını sağlıklı beslenme, ihtiyaçlara öncelik verme, parasını boşa harcamama, israf etmeme ve spor yapma gibi konularla ilişkilendirdikleri görülmektedir. Orta ve üst sosyoekonomik çevrede bulunan ilkokullarda öğrenim gören öğrencilerin ise alt sosyoekonomik çevrede bulunan ilkokulda öğrenim gören öğrencilerin ifadelerine ek olarak bilinçli tüketicilik kavramını haklarını korumak, para biriktirmek, çevreyi korumak, elektrik, su, doğalgaz gibi kaynakları boşa harcamamak, alacağı ürünün en iyisini almak gibi ifadelerle ilişkilendirdikleri görülmektedir. Tablo 7'deki verilere dayalı olarak orta ve üst sosyoekonomik çevredeki ilkokullarda öğrenim gören öğrencilerin alt sosyoekonomik çevredeki ilkokulda öğrenim gören öğrencilere göre bilinci tüketicilik kavramının tanımını daha geniş boyutta değerlendirdikleri ifade edilebilir. Araştırmanın nicel boyutunda kullanılan ölçek aracılığıyla elde edilen veriler, üst ve orta sosyoekonomik çevrelerdeki ilkokullarda öğrenim gören öğrencilerin alt sosyoekonomik çevredeki ilkokulda öğrenim gören öğrencilere göre daha yüksek ölçek puanı elde ettikleri yönündedir. Araştırmanın nitel boyutunda, öğrencilerin bilinçli tüketicilik kavramına ilişkin görüşleri ele alındığında elde edilen bulguların nicel bulgularla örtüştüğü ifade edilebilir.
Öğrencilerin bilinçli tüketicinin sergilemesi gereken davranışlara ilişkin görüşleri beş alt tema çerçevesinde ele alınmıştır. Söz konusu alt temalar Şekil 3 'te gösterilmiştir.

Şekil 3. Öğrencilerin Bilinçli Tüketicinin Tanımına İlişkin Görüşleri

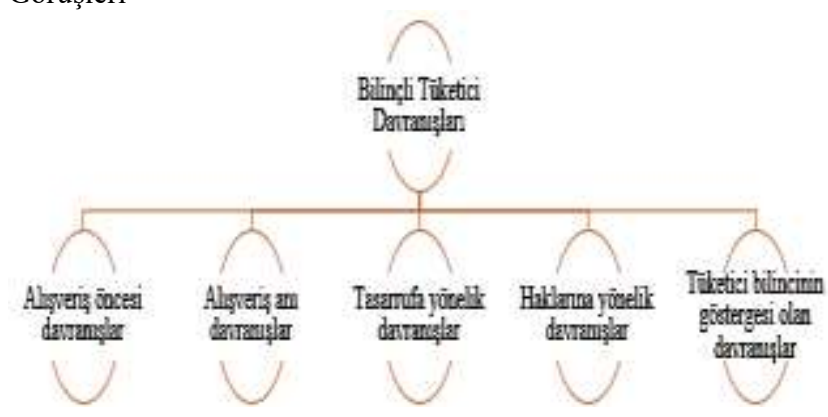

Şekil 3'de görüldüğü gibi, öğrencilerin bilinçli tüketicinin sergilemesi gereken davranışlara ilişkin görüşleri “Alışveriş öncesi davranışlar”, "Alışveriş anı davranışlar", "Tasarrufa yönelik davranışlar", "Haklarına yönelik davranışlar" ve "Tüketim bilincinin göstergesi olan davranışlar" alt temaları içerisinde ele alınmıştır. "Alışveriş öncesi davranışlar" ve "Alışveriş anı davranışlar" alt temaları öğrencilerin bilinçli tüketicinin alışveriş öncesi ve alışveriş anında sergilemesi gerektiğini ifade ettikleri davranışlara, "Tasarrufa yönelik davranışlar" alt teması ise öğrencilerin bilinçli tüketicinin parasının, kaynakların ve eşyaların tüketimi esnasında sergilemesi gereken davranışlara ilişkin görüşlerini kapsamaktadır. "Haklarına yönelik davranışlar" alt teması ögrrencilerin tüketicilerin sahip oldukları haklara ve sorun yaşayabilme ihtimaline karşılık ürünlerle ilgili dikkat etmeleri gereken güvence koşullarına ilişkin görüşlerini, "Tüketici bilincinin göstergesi olan davranışlar" alt teması ise öğrencilerin doğrudan alışverişle, tüketimle ya da haklarıyla ilgili olmayan ancak bilinçli bir tüketici olmanın göstergesi olan davranışlara ilişkin ifade ettikleri görüşlerini içermektedir. Gerçekleştirilen görüşmelere ilişkin örnek cümleler aşağıdaki gibidir.
"Cebindeki alışveriş listesine göre harekete eder, asla fazla bir şey almaz. Eğer gördüğü bir şey varsa hemen aklına liste gelir ve ona göre alır. Liste yapmazsa mesela ihtiyacı olmayan şeyleri alır. Liste yapmamışsa parası da biter." (Mustafa).
"CE damgası olup olmadığına bakmalı. Mesela boya kalemlerinin arkasında CE damgası olması gerekiyor. Olmadığında senin sağlığına zarar verebiliyor. O sağlıklı olup olmadığını gösteriyor. Mesela F.... C..... çok bilindik bir ürün. Onun arkasında hep bulunuyor zaten." (Nur).
"Doğal kaynakları korumak, yeteri kadar kullanmak. Benzin, su, elektrik, doğalgaz gibi kaynaklar, dikkatli kullanmak. Çünkü doğal kaynaklar hepsi bir gün tükenecek” (Talha).
"Kâğıtları, plastikleri geri dönüşüme atar, çünkü normal çöpe atsak yakılacak gidecek. Yine ağaç kesilecek ama geri dönüşüme atarsak o yine kâğıda dönecek, yine kullanacağı" (Yusuf).

Öğrencilerin bilinçli tüketicinin sergilemesi gereken davranışlara ilişkin ifade ettikleri görüşlerin okulun bulunduğu sosyoekonomik çevreye göre çeşitlilik 
gösterdiği belirlenmiştir. Söz konusu bulguya ilişkin bilgiler Tablo 8'de gösterilmiştir.

Tablo 8. Öğrencilerin Bilinçli Tüketici Davranışlarına İlişkin Görüşlerinin Okulun Bulunduğu Sosyoekonomik Çevreye Göre Dağılımı

\begin{tabular}{|c|c|c|c|}
\hline Bilinçli tüketicinin davranışları & Alt & Orta & $\overline{\text { Üst }}$ \\
\hline \multicolumn{4}{|l|}{ Alıșveriş öncesi davranışlar } \\
\hline Alışverişten önce liste yapar & $\checkmark$ & $\checkmark$ & $\checkmark$ \\
\hline Alışverişten önce araştırma yapar & $\checkmark$ & $\checkmark$ & $\checkmark$ \\
\hline Bütçe yapar & $\checkmark$ & & \\
\hline İhtiyaçlarına öncelik verir & $\checkmark$ & $\checkmark$ & $\checkmark$ \\
\hline $\begin{array}{l}\text { Alışverişten yanında yetecek kadar } \\
\text { para bulundurur }\end{array}$ & $\checkmark$ & & $\checkmark$ \\
\hline \multicolumn{4}{|l|}{ Alışveriş anı davranışlar } \\
\hline Ürünün SKT kontrol eder & $\checkmark$ & $\checkmark$ & $\checkmark$ \\
\hline Ürünün TSE damgasını kontrol eder & $\checkmark$ & $\checkmark$ & $\checkmark$ \\
\hline Ürünün ambalajını kontrol eder & & $\checkmark$ & \\
\hline Ürünün saklama koşullarına dikkat eder & & & $\checkmark$ \\
\hline Ürünün CE damgasını kontrol eder & & & $\checkmark$ \\
\hline Ürünlerin içindekiler bölümünü okur & & $\checkmark$ & $\checkmark$ \\
\hline Alacağı ürünün kalitesine önem verir & $\checkmark$ & $\checkmark$ & $\checkmark$ \\
\hline Ucuz ürünler almaz & & $\checkmark$ & $\checkmark$ \\
\hline \multicolumn{4}{|l|}{ Tasarrufa yönelik davranışlar } \\
\hline Kaynakları israf etmez & $\checkmark$ & $\checkmark$ & $\checkmark$ \\
\hline Parasını boşa harcamaz & $\checkmark$ & $\checkmark$ & $\checkmark$ \\
\hline Para biriktirir & $\checkmark$ & $\checkmark$ & $\checkmark$ \\
\hline Eski eşyaları değerlendirir & & $\checkmark$ & \\
\hline \multicolumn{4}{|l|}{ Haklarına yönelik davranışlar } \\
\hline Haklarını savunur & $\checkmark$ & $\checkmark$ & \\
\hline Aldığg ürünün fişini alır & $\checkmark$ & $\checkmark$ & $\checkmark$ \\
\hline Garanti belgeli ürünleri tercih eder & $\checkmark$ & $\checkmark$ & $\checkmark$ \\
\hline \multicolumn{4}{|l|}{ Tüketici bilincinin göstergesi olan davranışlar } \\
\hline Spor yapar & & $\checkmark$ & $\checkmark$ \\
\hline Çevreyi korur & & $\checkmark$ & $\checkmark$ \\
\hline Sağlıklı beslenir & & $\checkmark$ & $\checkmark$ \\
\hline Reklamlara kanmaz & $\checkmark$ & $\checkmark$ & $\checkmark$ \\
\hline Yerli malı kullanmaya özen gösterir & & & $\checkmark$ \\
\hline Paylaşımcı davranır & & & $\checkmark$ \\
\hline Çevresindeki insanları uyarır & & & $\checkmark$ \\
\hline Ailesinin uyarılarını dikkate alır & & & $\checkmark$ \\
\hline Okul eşyalarına zarar vermez & & & $\checkmark$ \\
\hline
\end{tabular}

Tablo 8 incelendiğinde, her üç sosyoekonomik çevredeki ilkokulda öğrenim gören öğrencilerin de belirlenen bütün alt temalara ilişkin görüş bildirdikleri görülmektedir. Bununla birlikte alt sosyoekonomik çevredeki ilkokulda öğrenim gören öğrencilerin başta "Alışveriş öncesi davranışlar" olmak üzere, "Tasarrufa yönelik davranışlar" ve "Haklarına yönelik davranışlar" alt temalarına odaklandıkları görülmektedir. Orta ve üst sosyoekonomik çevredeki ilkokullarda öğrenim gören öğrencilerin bütün temalara ilişkin görüş bildirdikleri ve bu yöndeki görüşlerinin alt sosyoekonomik çevredeki ilkokulda öğrenim gören öğrencilerden daha kapsamlı olduğu, üst sosyoekonomik çevredeki ilkokulda öğrenim gören öğrencilerin tüketim bilincinin göstergesi olan davranışlara ilişkin daha kapsamlı tanımlamalarda bulundukları ifade edilebilir. Araştırmanın nicel boyutunda kullanılan ölçek aracılığıyla elde edilen veriler, üst ve orta sosyoekonomik çevrelerdeki ilkokullarda öğrenim gören öğrencilerin alt sosyoekonomik çevredeki ilkokulda öğrenim gören öğrencilere göre daha yüksek ölçek puanı elde ettikleri yönündedir. Öğrencilerin bilinçli tüketicinin sergilemesi gereken davranışlara ilişkin görüşlerinden elde edilen bulgular ele alındığında orta ve üst sosyoekonomik çevredeki ilkokullarda öğrenim gören öğrencilerin bilinci bir tüketicinin sergilemesi gereken davranışları daha geniş boyutta değerlendirdikleri görülmektedir. $\mathrm{Bu}$ kapsamda elde edilen nitel bulguların nicel bulgularla örtüştüğü ifade edilebilir.

Öğrencilerin kendilerine yönelik tüketicilik algılarını iki ana boyutta değerlendirdikleri belirlenmiştir. Bu boyutlar "Olumlu tüketicilik algısı" ve "Olumsuz tüketicilik algısı" biçiminde tanımlanmıştır. Öğrencilerin kendilerine yönelik olumlu tüketicilik algılarının nedenlerini ifade ettikleri görüşleri beş alt tema çerçevesinde ele alınmıştır. Söz konusu alt temalar Şekil 4'de gösterilmiştir.

Şekil 4. Öğrencilerin Kendilerine Yönelik Sahip Oldukları Olumlu Tüketicilik Algılarının Nedenlerine İlişkin Görüşleri

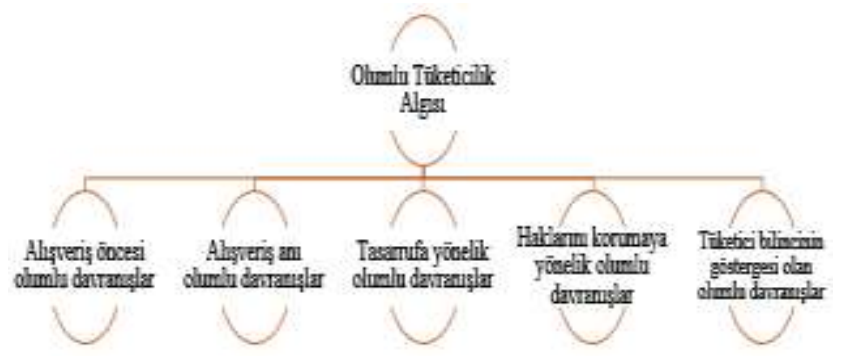

Şekil 4'te görüldüğü gibi, öğrencilerin kendilerine yönelik sahip oldukları olumlu tüketicilik algılarının nedenlerine ilişkin görüşleri "Alışveriş öncesi olumlu davranışlar", "Alışveriş anı olumlu davranışlar", "Tasarrufa yönelik olumlu davranışlar", "Haklarını korumaya yönelik olumlu davranışlar" ve "Tüketim bilincinin göstergesi olan olumlu davranışlar" alt temaları çerçevesinde ele alınmıştır. "Alışveriş öncesi olumlu davranışlar" ve "Alışveriş anı olumlu davranışlar" alt temaları içerisinde öğrencilerin bilinçli bir tüketici olarak alışveriş öncesi ve alışveriş anında sergilediklerini ifade ettikleri olumlu davranışlara ilişkin görüşleri yer almaktadır. "Tasarrufa yönelik olumlu davranışlar" alt teması öğrencilerin bilinçli bir tüketici olarak paralarının, kaynakların ve ürünlerin tüketimi esnasında sergiledikleri olumlu davranışlarla ilişkin görüşlerini, "Haklarını korumaya yönelik olumlu davranışlar" alt teması öğrencilerin bilinçli bir tüketici olarak haklarını ve kendilerini güvence altına almaya yönelik sergiledikleri olumlu davranışlara ilişkin görüşlerini içermektedir. "Tüketici bilincinin göstergesi olan olumlu davranışlar" alt teması ise öğrencilerin doğrudan alışverişle, tüketimle ya da haklarıyla ilgili olmayan ancak bilinçli bir tüketici olarak sergiledikleri olumlu davranışlara ilişkin görüşlerini kapsamaktadır. Öğrencilerle gerçekleştirilen görüşmelere ilişkin örnek cümleler aşağıdaki gibidir.

\footnotetext{
"Bakıyorum, fiyat araştırması yapıyorum. Ürün pahalıysa almıyorum onu. Bütçeme göre yapıyorum araştırmayı." (Talha).
}

"Markası bildiğim bir şeyse mesela onu alırım çünkü şık olur. Markasını biliyorsam genellikle daha kaliteli olur." (Mustafa).

"Mesela banyoya girdiğim zaman banyonun 1şığını açık bırakmıyorum. Ellerimi yıkadığım 
zaman suyu açık bırakmıyorum. Kombi açık onu kapatıyorum boş yere yanmıyor" (Melike).

"Başkalarının hatalarını gideriyorum. Örneğin, dışarıda çöp kutusu var. Babam ve annem çikolata yediler diyelim. Kabuğunu falan tam yere atacakken ben o çöpü çöpe götürüp atıorum" (Emre).

Öğrencilerin kendilerine yönelik sahip oldukları olumlu tüketicilik algılarının nedenlerine ilişkin ifade ettikleri görüşlerin okulun bulunduğu sosyoekonomik çevreye göre çeşitlilik gösterdiği belirlenmiştir. Söz konusu bulguya ilişkin bilgiler Tablo 9'da gösterilmiştir.

Tablo 9. Öğrencilerin Kendilerine Yönelik Sahip Oldukları Olumlu Tüketicilik Algılarının Nedenlerine İlişkin Görüşlerinin Okulun Bulunduğu Sosyoekonomik Çevreye Göre Dağılımı

\begin{tabular}{lccc}
\hline Olumlu tüketicilik algısının nedenlerine & Alt & Orta & Üst \\
ilişkin davranışlar & & & \\
\hline Alışveriş öncesi olumlu davranışlar & & & \\
Liste yaparım & & $\checkmark$ & $\checkmark$ \\
Fiyat araştırması yaparım & $\checkmark$ & $\checkmark$ & $\checkmark$ \\
İhtiyaçlarıma öncelik veririm & $\checkmark$ & $\checkmark$ & $\checkmark$ \\
İhtiyacım kadar para bulundururum & $\checkmark$ & & \\
\hline Alı̧̧veriş anı olumlu davranışlar & & & \\
Ürünün SKT kontrol ederim & $\checkmark$ & $\checkmark$ & $\checkmark$ \\
Ürünün TSE damgasını kontrol ederim & $\checkmark$ & $\checkmark$ & $\checkmark$ \\
Ürünün kalitesine dikkat ederim & $\checkmark$ & $\checkmark$ & $\checkmark$ \\
Ürünün markasına dikkat ederim & & $\checkmark$ & $\checkmark$ \\
\hline Tasarrufa yönelik olumlu davranışlar & & & \\
Para biriktiririm & $\checkmark$ & $\checkmark$ & \\
Kaynakları dikkatli kullanırım & & $\checkmark$ & $\checkmark$ \\
Ürünleri israf etmem & & $\checkmark$ & \\
\hline Haklarını korumaya yönelik olumlu davranışlar & & \\
Haklarımı savunurum & & $\checkmark$ & $\checkmark$ \\
Satın aldığım ürünün fişini alırım & $\checkmark$ & $\checkmark$ & $\checkmark$ \\
Garanti belgeli ürünleri tercih ederim & $\checkmark$ & & \\
\hline Tüketici bilincinin göstergesi olan olumlu davranışlar & & \\
Sağlıklı beslenirim & $\checkmark$ & $\checkmark$ & $\checkmark$ \\
Çevreyi korurum & & $\checkmark$ & $\checkmark$ \\
Spor yaparım & & $\checkmark$ & $\checkmark$ \\
Ailemin uyarılarını dikkate alırım & $\checkmark$ & $\checkmark$ & $\checkmark$ \\
Eşyalarımı başkalarıyla paylaşırım & & & $\checkmark$ \\
Çevremi tüketim konularında uyarırım & & $\checkmark$ & $\checkmark$ \\
Başkalarının hatalarını gideririm & & $\checkmark$ & $\checkmark$ \\
\hline
\end{tabular}

Tablo 9'daki veriler incelendiğinde, her üç sosyoekonomik çevredeki ilkokulda öğrenim gören öğrencilerin de kendilerine yönelik sahip oldukları olumlu tüketicilik algılarına ilişskin düşüncelerinin nedenlerini ifade ederken belirlenen bütün alt temalara dair görüş bildirdikleri görülmektedir. Bununla birlikte orta ve üst sosyoekonomik çevredeki ilkokullarda öğrenim gören öğrencilerin kendilerine yönelik olumlu tüketicilik algılarını gerekçelendirirken "Tüketim bilincinin göstergesi olan olumlu davranışlar" alt temasına ilişkin alt sosyoekonomik çevredeki ilkokulda öğrenim gören öğrencilere göre daha kapsamlı görüş bildirdikleri görülmektedir. Alt sosyoekonomik çevredeki ilkokulda öğrenim gören öğrencilerin kendilerine yönelik sahip oldukları olumlu tüketicilik algılarını gerekçelendirirken genel olarak "Alışveriş öncesi olumlu davranışlar" ve "Alışveriş anı olumlu davranışlar" alt temalarına ilişkin konulara odaklandıkları görülmektedir. Sonuç olarak orta ve üst sosyoekonomik çevrelerdeki ilkokullarda öğrenim gören öğrencilerin alt sosyoekonomik çevredeki ilkokulda öğrenim gören öğrencilere göre kendilerine yönelik sahip oldukları olumlu tüketicilik algılarını gerekçelendirirken daha kapsamlı ifadeler kullandıkları belirlenmiştir. $\mathrm{Bu}$ bulgunun araştırmanın nicel boyutunda elde edilen, üst ve orta sosyoekonomik çevrelerdeki ilkokullarda öğrenim gören öğrencilerin alt sosyoekonomik çevredeki ilkokulda öğrenim gören öğrencilere göre daha yüksek ölçek puanı elde ettikleri yönündeki sonuçla örtüştüğü savunulabilir.

Öğrencilerin kendilerine yönelik sahip oldukları olumsuz tüketicilik algılarının nedenlerini ifade ettikleri görüşleri beş alt tema çerçevesinde ele alınmıştır. Söz konusu alt temalar Şekil 5'de gösterilmiştir.

Şekil 5. Öğrencilerin Kendilerine Yönelik Sahip Oldukları Olumsuz Tüketicilik Algılarının Nedenlerine İlişkin Görüşleri

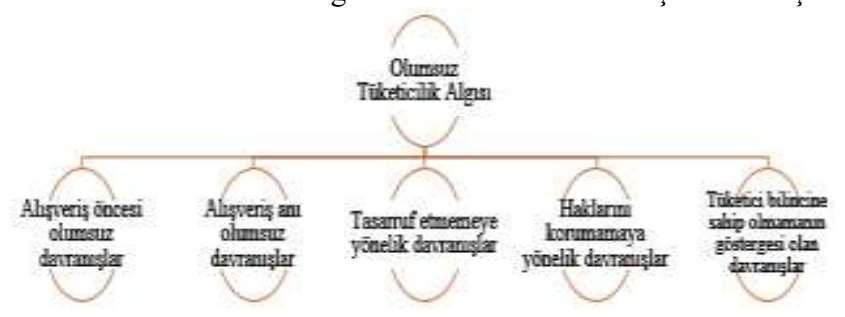

Öğrencilerin kendilerine yönelik sahip oldukları olumsuz tüketicilik algılarının nedenlerine ilişkin görüşlerine dayalı olarak belirlenen "Alışveriş öncesi olumsuz davranışlar" ve "Alışveriş anı olumsuz davranışlar" alt temaları içerisinde alışveriş öncesi ve alışveriş anında sergilediklerini ifade ettikleri olumsuz davranışlara ilişkin görüşleri yer almaktadır. "Tasarrufa etmemeye yönelik davranışlar" alt temasında öğrencilerin paralarının, kaynakların ve ürünlerin tüketimi esnasında sergiledikleri olumsuz davranışlarla ilişkin görüşlerine yer verilmiştir. "Haklarını korumamaya yönelik davranışlar" alt teması içerisinde öğrencilerin bilinçli bir tüketici olarak haklarını ve kendilerini güvence altına almamaya yönelik sergiledikleri olumsuz davranışlara ilişkin görüşleri yer almaktadır. "Tüketici bilincine sahip olmamanın göstergesi olan davranışlar" alt teması ise öğrencilerin doğrudan alışverişle, tüketimle ya da haklarıyla ilgili olmayan, sergilenmesi dolaylı olarak tüketim bilicinin göstergesi olan ancak bir tüketici olarak bu davranışlara ilişkin olumsuz yaşantılar sergilediklerini ifade ettikleri görüşlerini kapsamaktadır. Öğrencilerle gerçekleştirilen görüşmelere ilişkin örnek cümleler aşağıdaki gibidir.
"Mesela para biriktirdiğimde bilinçli hissediyorum kendimi ama liste yapmadığımdan dolayı kendimi bilinçsiz hissediyorum” (Serhat).
“...çünkü her şeyi alırım. Beğendiğim her şeyi, varsa ve gereksizse de alırım ben. Mesela kıyafete çok düşkünüm, her gün başka bir şey giyinirim evde. Yemek te olabilir" (İclal).
"Ben 1şıkları bazen banyodan çıktıktan sonra, dişlerimi firçaladıktan sonra açık unutabiliyorum. Babam bazen kızıyor bana elektriği kapat diye. Bazen unutuyorum odadan çıkınca falan. Bazen dişlerimi firçaladığımda diş macununun kapağını açı unutuyorum, kuruyor. Kuruyan yeri çıkarıp tekrar sürüyorum ama orası israf oluyor" (Zeynep). 
"Bazen alışveriş yaptıktan sonra fiş almıyorum. Unutuyorum işte. Son kullanma tarihini öğrenmek için, kaliteli olup olmadığını öğrenmek için, fiyatını karşılaştırmak için fiş almalıyız. Fiş almayı unutuyorum. Bazen fiş alıyorum bazen almiyorum" (Erol).

"Alışveriş anında annemi bazen çekiştiriyorum, bunu ne zaman alabiliriz diye. Mesela ben yolda gördüğüm bir şey istemiştim, yemek olarak istemiştim. Annem de hayır dedi evde yemek var dedi. Onu iyice çekiştirdim orada. Orada yanlış yapmıştım. Ekmek arası bir şeydi” (Mustafa).

Öğrencilerin kendilerine yönelik sahip oldukları olumsuz tüketicilik algılarının nedenlerine ilişkin ifade ettikleri görüşlerin okulun bulunduğu sosyoekonomik çevreye göre çeşitlilik gösterdiği belirlenmiştir. Söz konusu bulguya ilişkin bilgiler Tablo 10'da gösterilmiştir.

Tablo 10. Öğrencilerin Kendilerine Yönelik Sahip Oldukları Olumsuz Tüketicilik Algılarının Nedenlerine İlişkin Görüşlerinin Okulun Bulunduğu Sosyoekonomik Çevreye Göre Dağılımı

\begin{tabular}{llcc}
\hline $\begin{array}{l}\text { Olumsuz tüketicilik algısının nedenlerine } \\
\text { ilişkin davranışlar }\end{array}$ & Alt & Orta & Üst \\
\hline Alışveriş öncesi olumsuz davranışlar & & & \\
Alışverişten önce liste yapmam & & & $\checkmark$ \\
\hline Alışveriş anı olumsuz davranışlar & & & $\checkmark$ \\
Ürünün SKT kontrol etmem & $\checkmark$ & $\checkmark$ & \\
Beğendiğim her şeyi almak isterim & $\checkmark$ & & $\checkmark$ \\
\hline Tasarruf etmemeye yönelik davranışlar & & & \\
Para biriktirmem & $\checkmark$ & & \\
Kaynakları kötü kullanırım & & $\checkmark$ & $\checkmark$ \\
Ürünleri israf ederim & & $\checkmark$ & \\
\hline Haklarını korumamaya yönelik davranışlar & & & \\
Alışverişten sonra fiş almam & $\checkmark$ & $\checkmark$ & \\
\hline Tüketici bilincine sahip olmamanın göstergesi olan davranışlar \\
Sağlıklı beslenmem & $\checkmark$ & & $\checkmark$ \\
Reklamlara kanarım & $\checkmark$ & & \\
Ailemin kararlarını olumsuz etkilerim & $\checkmark$ & $\checkmark$ & \\
Çevremi temiz tutmam & \multicolumn{2}{c}{$\checkmark$} & $\checkmark$ \\
\hline
\end{tabular}

Tablo 10 incelendiğinde alt, orta ve üst sosyoekonomik çevrelerdeki ilkokullarda öğrenim gören ve kendisine yönelik olumsuz tüketicilik algısına sahip olan öğrencilerin bu yöndeki düşüncelerinin nedenlerini ifade ederken "Alışveriş öncesi olumsuz davranışlar" alt teması dışında kalan bütün alt temalara ilişkin görüş bildirdikleri belirlenmiştir. Bununla birlikte üst sosyoekonomik çevredeki ilkokulda öğrenim gören öğrencilerin kendilerine yönelik sahip oldukları olumsuz tüketicilik algılarını gerekçelendirirken "Alışveriş öncesi sergiledikleri olumsuz davranışlar" alt temasına ilişkin de görüş ifade ettikleri görülmektedir. Ayrıca alt sosyoekonomik çevredeki ilkokulda öğrenim gören öğrenciler orta ve üst sosyoekonomik çevredeki ilkokullarda öğrenim gören öğrencilerden farklı olarak para biriktirmeme ve reklamlara kanma davranışlarını sergilediklerini ifade etmişlerdir. Orta sosyoekonomik çevredeki ilkokullarda öğrenim gören öğrenciler ise alt ve üst sosyoekonomik çevredeki ilkokullarda öğrenim gören öğrencilerden farklı olarak ürünleri israf ettiklerini dile getirmişlerdir.

Öğrencilerin sahip oldukları tüketici haklarına ilişkin görüşleri üç alt tema içerisinde ele alınmıştır. Söz konusu alt temalar Şekil 6'da gösterilmiştir.
Şekil 6. Öğrencilerin Sahip Oldukları Tüketici Haklarına İlişkin Görüşleri

Tüketici Haklan

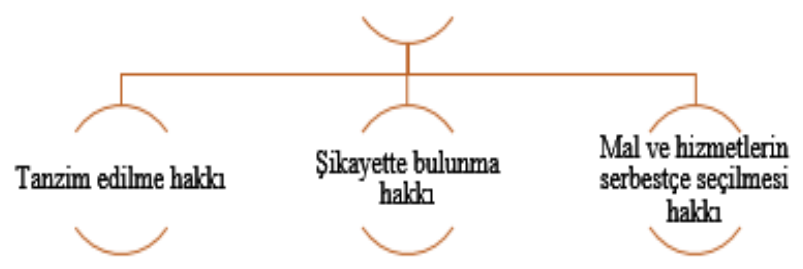

Öğrenciler sahip oldukları tüketici haklarını ifade ederken yaptıkları tanımlamalarda "Tanzim edilme", "Şikâyette bulunma" ve "Mal ve hizmetleri serbestçe seçme" haklarını ima edici biçiminde görüş bildirdikleri görülmüştür. Yapılan tanımlamalar incelendiğinde öğrencilerin genel olarak sorun yaşanılan bir ürünle ilgili iade ederim, değiştiririm ve geri veririm gibi ifadeleriyle tanzim edilme hakkına vurgu yaptıkları, şikâyet ederim, tüketici haklarına başvururum gibi ifadeleriyle de şikâyette bulunma hakkına vurgu yaptıkları görülmüştür. Bunların yanı sıra sıklığı az olmakla birlikte öğrencilerin mal ve hizmetlerin serbestçe seçilmesi hakkına vurgu yapan istediğim ürünü seçebilirim, ihtiyacımı karşılayabilecek ürünü seçebilirim gibi ifadeleri de kullandıkları da görülmüştür. Genel olarak değerlendirildiğinde öğrencilerin tüketici olarak sahip oldukları haklar arasında "Tanzim edilme", "Şikâyette bulunma ve "Mal ve hizmetlerin serbestçe seçilmesi" hakları konusunda bilgi sahibi oldukları biçiminde yorumda bulunulabilir. Gerçekleştirilen görüşmelerden elde edilen aşağıdaki örnek cümleler bu bulguyu desteler niteliktedir.
"Markette bir şey alınca değişme hakkım var. Mesela bozuksa veya beğenmediysem hiç açmadıysam onu geri götürüp değiştirebilirim fişiyle. Fiş onu o marketten aldığını ve kaç lira olduğunu gösteriyor" (İclal).
“...Mesela almazlarsa fişini gösteririm. O zaman mahkemeye başvururum, tüketici hakları mahkemesi... Onlar bir kişi hakkımı vermezse onu cezalandırırlar" (Zeynep). kabul etmezlerse fişini yine gösteririm, israr ederim hatta tekrar bir tane ürün daha gösteririm. Onun da özürlü olduğunu gösteririm. Almazlarsa
"Tüketici olarak bir ürün aldığında başkası seni engelleyemez. Hiç kimse seni engelleyemez. Bilinçli bir tüketiciysen kendin bakabilirsin. İstediğini seçebilirsin alacaklarının. O kendini bağlar" (Çağatay).

Öğrencilerin tüketici olarak sahip oldukları haklara ilişkin ifade ettikleri görüşlerin okulun bulunduğu sosyoekonomik çevreye göre çeşitlilik gösterdiği belirlenmiştir. Söz konusu bulguya ilişkin bilgiler Tablo 11 'de gösterilmiştir.

Tablo 11. Öğrencilerin Kendilerine Yönelik Sahip Oldukları Olumsuz Tüketicilik Algılarının Nedenlerine İlişkin Görüşlerinin Okulun Bulunduğu Sosyoekonomik Çevreye Göre Dağılımı

\begin{tabular}{lccc}
\hline $\begin{array}{l}\text { Tüketici olarak sahip olunan haklar } \\
\text { bilgisi }\end{array}$ & Alt & Orta & Üst \\
\hline Tanzim edilme hakkı & $\checkmark$ & $\checkmark$ & $\checkmark$ \\
$\quad$ Şikâyette bulunma hakkı & $\checkmark$ & $\checkmark$ & $\checkmark$ \\
$\begin{array}{l}\text { Mal ve hizmetlerin serbestçe } \\
\text { seçilmesi hakkı }\end{array}$ & $\checkmark$ & $\checkmark$ \\
\hline
\end{tabular}


Tablo 11 incelendiğinde, araştırmaya katılan alt, orta ve üst sosyoekonomik çevredeki ilkokullarda öğrenim gören öğrencilerin "Tanzim edilme" ve "Şikâyette bulunma" haklarına sahip olduklarını ifade ettikleri görülmektedir. Bununla birlikte orta ve üst sosyoekonomik çevrelerdeki ilkokulda öğrenim gören öğrencilerin ayrıca "Mal ve hizmetlerin serbestçe seçilmesi” hakkına sahip olduklarına ilişkin görüş bildirdikleri ancak alt sosyoekonomik çevredeki ilkokulda öğrenim gören öğrencilerin bu yönde bir ifade kullanmadikları belirlenmiştir. Elde edilen bulgular 1şı̆̆ında, araştırmaya katılan orta ve üst sosyoekonomik çevrelerdeki ilkokullarda öğrenim gören öğrencilerin, araştırmaya katılan alt sosyoekonomik çevredeki ilkokulda öğrenim gören öğrencilere göre tüketici haklarına ilişkin daha kapsamlı bilgiye sahip oldukları biçiminde yorumda bulunulabilir. $\mathrm{Bu}$ bulgunun araştırmanın nicel boyutunda elde edilen, üst ve orta sosyoekonomik çevrelerdeki ilkokullarda öğrenim gören öğrencilerin alt sosyoekonomik çevredeki ilkokulda öğrenim gören öğrencilere göre daha yüksek ölçek puanı elde ettikleri yönündeki sonuçlarla örtüştüğü savunulabilir.

\section{Sonuç, Tartışma ve Öneriler}

İlkokul 4. sınıf öğrencilerinin bilinçli tüketicilik durumlarının incelenmesinin amaçlandı ğı bu çalışma karma araştırma modeli tasarımlarından kısmen karma sıralı baskın desen kullanılarak gerçekleştirilmiştir. Araştırma verileri Sağlam (2010a) tarafından geliştirilen Bilinçli Tüketicilik Düzeyi Ölçeği, araştırmacı tarafından geliştirilen kişisel bilgi formu ve yarı-yapılandırılmış görüşme formu aracılığıyla elde edilmiştir. Araştırmada kullanılan Bilinçli Tüketicilik Düzeyi Ölçeği ve Kişisel Bilgi Formuna dayalı veriler Eskişehir ili Tepebaşı ve Odunpazarı ilçelerinde alt, orta ve üst sosyoekonomik düzeylerden 15 ilkokulun 4. sinıf öğrencilerinin katılımlarıyla elde edilmiştir. Elde edilen ölçek verileri SPSS 21 programı aracılığıyla istatistiksel olarak analiz edilmiştir. Karşılaştırmalar yapılırken kişisel bilgi formu aracılı̆̆ıyla elde edilen öğrencilerin demografik özellikleri dikkate alınmıştır. Yarı-yapılandırılmış görüşmelere dayalı veriler, ölçek puanları dikkate alınarak her sosyoekonomik düzeyi temsil eden öğrencilerden elde edilmiştir. Yarı yapılandırılmış görüşmeler 15 öğrencinin katılımıyla gerçekleştirilmiştir. Görüşme verileri tematik analiz tekniği kullanılarak çözümlenmiştir.

Araştırma bulgularına göre; okulun bulunduğu çevrenin sosyoekonomik düzeyi arttıkça öğrencilerin de bilinçli tüketicilik farkındalıklarının arttığı; buna göre orta ve üst sosyoekonomik çevredeki ilkokullarda öğrenim gören öğrenciler "her zaman" biçiminde ifade edilen üst düzey tüketici bilincine sahip iken, alt sosyoekonomik çevredeki ilkokulda öğrenim gören öğrencilerin "çoğu zaman" biçiminde ifade edilen daha düşük düzeyde bir tüketici bilincine sahip oldukları belirlenmiştir. Alan yazın incelendiğinde üst sosyoekonomik çevredeki okullarda öğrenim gören öğrencilerin daha düşük sosyoekonomik çevredeki okullarda öğrenim gören öğrencilere göre tüketici bilinçlerinin daha yüksek olduğunu belirten çalışmalara rastlanmaktadır (Ersoy, 2005; Purutçuoğlu, 2003). Bununla birlikte sosyoekonomik çevrenin tüketici bilinci üzerine etki eden bir faktör olmadığını belirten çalışmalara da rastlanmaktadır (Akyüz, 2009; Altık, 2010; Sağlam, 2010b). Alan yazında sosyoekonomik çevrenin tüketim bilinci üzerinde etkili bir değişken olup olmadığına ilişkin elde edilen farklı bulguların en temel nedeni, araştırmaların gerçekleştirildiği örneklem kitlesinin sosyoekonomik düzey farklılıklarını tam anlamıla yansıtmaması olabilir. Bu araştırma kapsamında sosyoekonomik düzey faktörüne göre örneklem belirlenirken il milli eğitim müdürlügüünün verileri dikkate alınmıştır. Bu veriler araştırma kapsamında uygulanan Kişisel Bilgi Formu'nda yer alan ailenin aylık gelir durumuna ilişkin veriler ile de karşılaştırılarak teyit edilmeye çalışılmıştır. $\mathrm{Bu}$ çalışma kapsamında sosyoekonomik çevrenin tüketim bilincini belirleyici bir değişken olarak ortaya çıkması bu kapsamda değerlendirilebilir.

Ailenin gelir düzeyi arttıkça öğrencilerin bilinçli tüketicilik düzeylerinin $\operatorname{arttığı~sonucuna~ulaşılmıştır.~Yapılan~}$ çalışmalar incelendiğinde, yüksek gelirli ailelerin çocuklarının tüketime yönelik bilgi ve bilinç düzeylerinin (Ersoy, 2005; Ersoy, Demirci ve Ersoy, 2007; Ersoy ve Nazik, 2006) ve tüketime yönelik sosyal motivasyonlarının (Dursun, 1993) düşük gelirli ailelerin çocuklarından daha fazla olduğu, gelir düzeyi yüksek ailelerin çocuklarının paraya ilişkin deneyimlerinin düşük gelirli ailelerin çocuklarından daha fazla olduğu ve bu durumun tüketim konularında daha bilgili olmalarına yol açtığına yönelik bulgulara rastlanmaktadır (Ward, 1974). Bu bulguların yanı sıra ailenin aylık gelir düzeyinin, öğrencilerin tüketicilik bilgi ve bilinç düzeyleri üzerinde belirleyici bir değişken olmadığını ortaya koyan çalışmalara da rastlanmıştır (Akyüz, 2009; Altık, 2010; Sağlam, 2010b). Bu çalışmada ailenin gelir düzeyi ile öğrencilerin bilinçli tüketicilik düzeyleri arasında pozitif yönlü bir ilişki saptanmasının nedeni, ailenin sosyoekonomik düzeyi ile öğrencilerin tüketime ilişkin deneyimleri arasındaki ilişkinin niteliğinden kaynaklı olabilir. Buna göre, düşük sosyoekonomik düzeye sahip ailelerin ekonomik imkanlarının yüksek sosyoekonomik düzeye sahip ailelerin ekonomik imkanlarına göre daha kısıtlı olması, çocuklarının da daha sınırlı bir ekonomik deneyim yaşamalarına, bu nedenle bilinçli tüketicilik düzeylerinin niceliksel anlamda daha düşük olmasına neden olmuş olabilir.

Cinsiyetin öğrencilerin bilinçli tüketicilik düzeyleri üzerinde etkili bir değişken olmadığı belirlenmiştir. Alan yazın incelendiğinde, kız ve erkek ilkokul öğrencilerinin tüketici bilinç düzeyleri arasında farklılık bulunmadığını (Akyüz, 2009; Altıok, 2010; Kahyaoğlu ve Kırıktaş, 2010; Sağlam, 2010b) belirten çalışmalar yer almaktadır. Ancak bu konuda kız ve erkek öğrencilerin bilinçli tüketicilik düzeyleri arasında fark olduğunu gösteren çalışmalara da rastlanmaktadır. Bu yöndeki çalışmalarda, kız öğrencilerin erkek öğrencilere göre daha üst düzey tüketici bilincine sahip oldukları belirtilmektedir (Ersoy, 2005; Ersoy ve Nazik, 2006; Purutçuoğlu, 2003). Bilimsel araştırmalarda katılımcıların cinsiyetinin bağımlı değişkenle ilişkisi sıklıkla irdelenmektedir. Bununla birlikte, cinsiyetin araştırmanın konusu özelinde bir değişken niteliği taşımadığ1 durumlarda söz konusu olabilir. Bu çalışma ilkokul 4. sınıf öğrencileri ile gerçekleştirilmiştir. Dolayısı ile ilkokul çağındaki öğrenciler cinsiyet durumları tüketim bilinci düzeyi açısından belirleyici bir değişken olmayabilir. Öyle ki, aynı sosyoekonomik düzeye sahip ailelerden gelen ilkokul çağındaki öğrencilerin kız ya da erkek olsun tüketime ilişkin deneyimlerinin birbirine benzer nitelikte 
olduğu söylenebilir. Bu çalışma kapsamında araştırmaya katılan bütün öğrencilerin ölçme aracindan elde ettikleri puanlar ölçüt alınarak ve sosyoekonomik düzey farklılığı gözetilmeksizin cinsiyet değişkeni ile bilinçli tüketicilik düzeyi arasındaki olası bir ilişkinin varlığı ortaya konulmaya çalışıldığından, her iki değişken arasında anlamlı bir farklılık ortaya çıkmamış olması doğal karşılanabilir. Eğer sosyoekonomik düzeyler de dikkate alınarak cinsiyetin tüketim bilinci düzeyi üzerinde bir değişken olup olmadığı belirlenmeye çalışılsaydı anlamlı bir farklılığa ulaşılmış olunabilirdi. $\mathrm{Bu}$ durumun gerçekleştirilen çalışma bakımından bir eksiklik olduğu ifade edilebilir.

Annenin ve babanın eğitim düzeyi arttıkça öğrencilerin bilinçli tüketicilik düzeylerinin de arttığı sonucuna ulaşılmıştır. Alan yazında yer alan çalışmalar ele alındığında anne ve babanın eğitim düzeyindeki artışa paralel olarak öğrencilerin de bilinçli tüketiciliğe yönelik bilgi ve bilinç durumlarının artığını belirten çalışmalara rastlanmaktadır (Dursun, 1993; Ersoy, 2005; Ersoy ve Nazik, 2006). Ayrıca annenin eğitim düzeyindeki artışın öğrencilerin bilinci tüketicilik düzeyleri üzerine olumlu etki yaratmasına rağmen, babanın eğitim düzeyindeki artış ile öğrencilerin bilinçli tüketicilik düzeyle arasında bir bağlantının bulunmadığını belirten çalışmalar da bulunmaktadır (Sağlam, 2010b). Bununla birlikte, gerek annenin gerekse babanın eğitim düzeyi ile öğrencilerin bilinçli tüketicilik düzeyleri arasında bir ilişkinin bulunmadığını gösteren çalışmalara da rastlanmaktadır (Akyüz, 2009; Altıok, 2010).

Anne ve babanın mesleki durumunun öğrencilerin bilinçli tüketicilik düzeyleri üzerinde belirleyici bir etken olduğu belirlenmiştir. Buna göre gerek annesi gerekse babası çalışan öğrencilerin, çalışmayan öğrencilere göre daha üst düzey bir tüketici bilincine sahip oldukları sonucuna ulaşılmıştır. Alan yazındaki çalışmalar incelendiğinde öğrencilerin tüketici bilgi ve bilinç düzeylerinin özellikle annenin çalışıyor olma durumundan olumlu etkilendiğini, çalışan annelerin, çocuklarının ihtiyaçlarını satın alırken onların düşüncesini alma, yanlış tüketim davranışlarını uyarma, harçlıklarını nasıl değerlendirdiklerini kontrol etme konularında daha duyarlı davrandıklarını belirten bulgulara ulaşıldığ1 görülmektedir (Ersoy, 2005; Ersoy, Demirci ve Ersoy, 2007). Bununla birlikte, babanın mesleki durumunun öğrencilerin tüketici bilgi ve bilinç düzeyleri üzerinde belirleyici bir faktör olmadığı yönünde bulgulara da rastlanmaktadır (Ersoy, 2005). Annenin ekonomik yaşamın bir parçası olarak aile bütçesine katkıda bulunmasının ve bunun sonucu olarak ekonomik farkındalığının artmasının, ailenin tüketim alışkanlıklarının yönetimi konusunda annenin daha bilinçli kararlar almasını sağladığı savunulabilir. $\mathrm{Bu}$ bilinç durumu toplumsal yaşamın gereklerinin öğrenildiği ilk yer olan aile içinde, bu gerekleri öğretici en temel unsur olan annenin çocukların tüketim alışkanlıklarını da olumlu olarak şekillendirmesine yardımcı olacaktır. Bütün bu etkenler dikkate alındığında, annenin çalışıyor olma durumunun çalışmayan annelere göre çocukların bilinçli tüketicilik düzeylerini daha olumlu etkileyerek bilinçli tüketicilik düzeylerinin artmasını sağladığı biçiminde yorumlanabilir.

Öğrencilerin harçlık miktarlarının, bilinçli tüketicilik düzeyleri üzerinde belirleyici bir değişken olmadığı belirlenmiştir. Ancak; haçlıklarını biriktiren öğrencilerin harçlıklarından birikim yapmayan öğrencilere göre bilinçli tüketicilik düzeylerinin daha yüksek olduğu belirlenmiştir. Alan yazın incelendiğinde, yüksek miktarlarda harçlık alan öğrencilerin daha düşük miktarlarda harçlik alan öğrencilere göre daha yüksek tüketim bilincine sahip oldukları, düzenli olarak harçlık alan öğrencilerin tüketimle ilgili daha fazla sorumluluk üstlendikleri ve buna bağlı olarak para hakkında daha geniş bilgiye sahip olduklarından tüketim bilgi ve becerilerinin geliştiği sonuçlarına ulaşılmıştır (Abramovitch, \& arkadaşları, 1991; Ersoy, 2005; Ersoy ve Nazik, 2006). Bu bağlamda, alan yazında yer alan araştırma bulgularının bu çalışma kapsamında ulaşılan sonuçlarla örtüşmediği görülmektedir. Bu durumun nedeni olarak araştırmaya katılan öğrencilerin büyük çoğunluğunun birbirine yakın miktarda harçlık alıyor olması olabilir. Buna göre 478 öğrencinin 413'ü 1-10 TL arasında harçlık alırken, 53'ü 11-20 TL arası, 12'si ise 20 TL ve üzeri miktarda harçlık almaktadır. Tarama araştırmalarında iki grup arası karşılaştırmaların yapılabilmesi için gruptaki birey sayısının minimum 30 olması gerekmektedir. $\mathrm{Bu}$ durumda katılımcıların büyük çoğunluğunun bir düzeyde yığılmış olması, 20TL ve üzeri haftalık harçlık alan öğrencilerin sayısının 12 olması değişkenler arasında istatistiksel olarak anlamlı bir farklılığın oluşmasına engel olmuş olabilir. Bilinçli tüketicilik düzeyi ile öğrencinin elde ettiği haftalık harçlık miktarı arasındaki ilişkiye dair daha sağlıklı sonuçlara ulaşabilmek adına gruplardaki frekans sayılarının istatistiksel analize uygun dağılım gösterdiği örneklemlerle çalışılmasının gerekli olduğu söylenebilir.

Gerçekleştirilen görüşmelerde öğrencilerin bilinçli tüketici kavramına ilişkin görüşlerinden hareketle "Bilinçli tüketicinin tanımı", "Bilinçli tüketici davranışları", "Bilinçli tüketicilik algısı" ve “" Tüketici hakları" temalarına ulaşılmıştır. Öğrencilerin "Bilinçli tüketicinin tanımı" teması altındaki görüşleri "Para harcarken sergilenen davranışlar", "Tasarrufa yönelik davranışlar" ve "Tüketim bilincinin göstergesi olan davranışlar" alt temaları içerisinde ele alınmıştır. Buna göre öğrenciler bilinçli tüketiciyi ihtiyaçları doğrultusunda para harcayan, tasarruf yaparken kaynakları ve parasını israf etmeyen, tüketim bilincinin göstergesi olarak spor yapan, sağlıklı beslenen, haklarını ve çevreyi koruyan kişi biçiminde tanımlamışlardır.

Öğrencilerin "Bilinçli tüketici davranışlar" teması altındaki görüşleri "Alışveriş öncesi davranışlar", "Alışveriş anı davranışlar”, “Tasarrufa yönelik davranışlar”, Haklarına yönelik davranışlar" ve "Tüketim bilincinin göstergesi olan davranışlar" alt temaları içerisinde ele alınmıştır. Buna göre öğrenciler bilinçli bir tüketicinin alışveriş öncesinde liste, araştırma ve bütçe yapması, alışveriş anında ise ürünün özelliklerine ve kalitesine dikkat etmesi gerektiğine değinmişlerdir. Bunların yanı sıra bilinçli bir tüketicinin parasını ve kaynakları tüketirken dikkatli davranması ve haklarını gözetici tedbirler alması gerektiğini belirten öğrenciler aynı zamanda sağlıklı beslenme, spor yapma, eşyalara zarar vermeme ve çevreyi koruma gibi dolaylı olarak bilinçli tüketiciliğin göstergesi olan davranışlara da dikkat etmesi gerektiğini ifade etmişlerdir.

Öğrencilerin kendilerine yönelik tüketicilik algılarına ilişkin görüşleri "Bilinçli tüketici algısı”" teması içerisinde 
ele alınmıştır. Buna göre öğrencilerin kendilerine yönelik tüketicilik algıları "Olumlu tüketicilik algısı" ve "Olumsuz tüketicilik algısı" olmak üzere iki alt tema çerçevesinde değerlendirilmiştir. Her iki alt tema içerisinde öğrenciler alışveriş öncesi ve alışveriş anına, tasarrufa, haklarını korumaya ve dolaylı olarak tüketim bilincinin göstergesi olan davranışlara yönelik sergiledikleri olumlu ve olumsuz eylemleri gerekçe göstererek kendilerine yönelik sahip oldukları tüketicilik algılarını gerekçelendirmişlerdir. Ayrıca, öğrencilerin sahip oldukları tüketici haklarını ifade ederken yaptıkları tanımlamalarla "Tanzim edilme", "Şikâyette bulunma" ve "Mal ve hizmetleri serbestçe seçme" haklarını ima edici biçiminde görüş bildirdikleri belirlenmiştir.

Araştırmanın nitel boyutuna ilişkin bulgular genel olarak değerlendirildiğinde; sosyoekonomik koşulların tüketim bilinci üzerinde belirleyici bir faktör olduğu görülmüştür. Özellikle öğrencilerin bilinçli bir tüketicinin sergilemesi ve sergilememesi gereken davranışlara ilişsin görüşlerini ifade ederken alt sosyoekonomik düzeye sahip ailelerin çocukları ile orta ve üst sosyoekonomik düzeye sahip ailelerin çocuklarının ifadeleri arasında bilgi düzeyi bakımından büyük farklılıkların olduğu görülmüştür. Alt sosyoekonomik düzeye sahip ailelerin çocukları bilinçli tüketici davranışlarını büyük oranda alışveriş öncesi ve alışveriş anında sergilenmesi gereken davranışlar ile para tasarrufu üzerinden tanımlamışlardır. Oysa tüketim bilincinin sürdürülebilir çevre, sağlıklı beslenme ve toplumsal etki boyutlarına ilişkin bilgi düzeylerinin yetersiz olduğu görülmüştür. Bu boyutlara ilişkin ifadelerin başta üst sosyoekonomik düzeye sahip ailelerin çocukları olmak üzere k1smen de olsa orta sosyoekonomik düzeye sahi ailelerin çocuklarının görüşleri arasında yer aldığı gözlenmiştir. Öğrencilerin bilinçli tüketiciliğe ilişkin görüşlerini ifade ederken genellikle kendi deneyimlerinden yola çıktıkları düşünüldüğünde, alt sosyoekonomik düzeye sahip ailelerin çocuklarının ekonomik imkanların yetersiz olmasından dolayı tüketime ilişkin orta ve üst sosyoekonomik düzeye sahip ailelerin çocuklarına göre daha sınırlı bir deneyim yaşamaları bu konudaki görüşlerini de daha sınırlı ifadelerle yansıtmalarına neden olmuş olabilir. Ders kitaplarının tüketim bilincine ilişkin konuları incelendiğinde, özellikle tüketime ilişkin alışveriş öncesi, alışveriş anı ve alışveriş sonrasında sergilenmesi gereken davranışlar ve para tasarrufuna ilişkin uygulamalar üzerinde durulduğu görülmektedir. Dolayısıyla alt sosyoekonomik düzeye ait ailelerin çocuklarının tüketim bilincine ilişkin bilgilerinin öğretim programının öngördüğü içerikle örtüştüğü anlaşılmaktadır. Bu veriden hareketle tüketim bilincinin göstergesi olan diğer boyutlara ilişkin de öğrencilerin bilgi birikimlerinin gelişim göstermesi açısından, ders kitaplarında sürdürülebilir çevre, sağlıklı beslenme ve toplumsal etki boyutlarına yönelik konulara da yer verilmesi gerekmektedir.

Her ne kadar ölçeğin uygulandığı öğrenci grubunun genel olarak tüketime ilişkin bilinç düzeyleri yüksek çıksa da, öğrencilerle gerçekleştirilen görüşmeler neticesinde bilinçli tüketiciliğe ilişkin bilgi düzeylerinin belli kavramlar etrafinda şekillenmiş olduğu belirlenmiştir. Buna göre, öğrenciler gerek tüketici olarak sahip oldukları hakları gerekse bilinçli bir tüketicinin sergilemesi ve sergilememesi gereken davranışları ifade ederken sürekli benzer örnekler ve durumlar etrafinda görüşlerini ifade etmişlerdir.
Örneğin, öğrenciler tüketicilerin sahip oldukları hakları sıklıkla tanzim etme ve şikayette bulunma olarak ifade etmişlerdir. Sadece üst sosyoekonomik çevredeki okulda öğrenim gören öğrenciler üçüncü bir hak olarak mal ve hizmetleri serbestçe seçme hakkından bahsetmişlerdir. Tüketicilerin sahip olduğu onlarca hak arasından öğrencilerin sınırlı sayıda hakkı dile getirmiş olmaları özellikle öğretim programının bir eksikliği olarak düşünülebilir. Öyle ki İlkokul 4. sınıf Sosyal Bilgiler Dersi Öğretim Programı incelendiğinde bireylerin tüketicili olarak sahip oldukları hakların neler olduğuna yönelik bir kazanımın yer almadığı ayrıca programa göre hazırlanan ders kitaplarında da bu yönde bir konuya yer verilmediği görülmektedir. Öğrencilerle gerçekleştirilen görüşmelere verdikleri yanıtlardan da hareketle tüketici olarak sahip oldukları haklara ilişkin bilgilerinin genel olarak aileleriyle gerçekleştirdikleri alışveriş eylemleri üzerinden şekillendiği belirlenmiştir. Yenilenen öğretim programları incelendiğinde de gerek öğretim programlarında yer alan kazanımlar arasında gerekse hazırlanan ders kitaplarında yer alan konularda tüketici haklarına ilişkin bir bilgiye yer verilmemiştir. Dolayısıyla öğrencilerin tüketici olarak sahip oldukları haklara ilişkin bilgi eksikliklerinin kaynağının temel kaynağının bu yöndeki eksiklikten kaynaklandığı düşünülmektedir.

Genel olarak öğrencilerin bilinçli tüketicinin tanımına, sergilemesi gereken davranışlara, kendilerine yönelik tüketicilik algılarına ve sahip oldukları tüketici haklarına ilişkin ifade ettikleri görüşlerinin okulun bulunduğu sosyoekonomik çevreye göre çeşitlilik gösterdiği belirlenmiştir. Buna göre ifade edilen her bir durum için orta ve üst sosyoekonomik çevredeki ilkokullarda öğrenim gören öğrencilerin alt sosyoekonomik çevredeki ilkokulda öğrenim gören öğrencilere göre daha geniş boyutta değerlendirmelerde bulundukları görülmüştür. Araştırmanın nicel boyutunda kullanılan ölçek aracılığıyla elde edilen veriler, üst ve orta sosyoekonomik çevrelerdeki ilkokullarda öğrenim gören öğrencilerin alt sosyoekonomik çevredeki ilkokulda öğrenim gören öğrencilere göre daha yüksek ölçek puanı elde ettikleri yönündedir. Araştırmanın nitel boyutunda, öğrencilerin bilinçli tüketicilik kavramına ilişkin görüşleri ele alındığında elde edilen bulguların nicel bulgularla örtüştüğü ifade edilebilir.

Günümüzde bir hastalık gibi yayılan sürdürülebilirlikten uzak tüketim davranışları sadece bireylerin kendi ekonomilerini ve sağlıklarını etkilemekle kalmayarak, aynı zamanda yaşadığımız gezegeni ve bu bağlamda gelecek kuşakları da tehdit eder bir hal almaktadır. Gelinen noktada ihtiyaçları temin etmenin ötesinde bir var olma mücadelesi haline dönüştürülen tüketim kavramı, sanayileşmiş ülkeler ve küresel şirketlerin teknolojinin de desteğini alarak adeta insanlar üzerinde kurguladıkları bir bask1 unsuruna dönüşmektedir. Bireyler hatta toplumlar arasındaki sınırların en temel belirleyicisi konumuna yerleşen tüketim alışkanlığı kabul edilebilir bir zemine oturtulmadığı sürece, insanı ve her geçen gün tükettiği dünyayı tehdit eden bu kapandan kurtulmak mümkün olmayacaktır. Bu noktada bireyleri yaratılan zorunlu ve sınırsız tüketim algısından kurtaracak, kendisi, çevresi ve ekolojik yaşamın devamı için davranmaya koşullandıracak olgu, tüketim bilincine sahip olmaktır. 
Alan yazın incelendiğinde ülkemizde toplumsal tüketimin hızla arttığını (Terzi, 2012), tüketicilerin sorumluluklarına (Ortabostan, 1999) ve haklarına ilişkin bilgi durumlarının yetersiz olduğunu (Gürdal, 2003; Özbölük, 2010; Çavuşoğlu, 2006; Kor, 2007; Babaoğul ve Öztop, 1997; Yaman, 2002; Peker, 1993; Ortabostan, 1999), reklamların tüketicilerin satın alma kararlarını etkilediğini (Karabacak, 1993; Özbölük, 2010; Terzi, 2012), hazc1 tüketim eğiliminin artığını (Kırc1, 2014; Özdemir, 2007) ve bu yöndeki tüketimin bireylerin satın alma eğilimleri üzerinde bilişsel ve duygusal etkisi bulunduğunu (Akturan, 2010), tüketicilerin çevresel sürdürülebilir davranışlarının yetersiz düzeyde olduğunu (Ceylan, 2010) ve tüketici hakem heyetlerine yapılan başvuruların yıllara göre arttığını (Erer, 2010) vurgulayan çalışmalara rastlanmaktadır. $\mathrm{Bu}$ çalışmalar 1şığında ülkemiz özelinde yetişkin tüketicilerin tüketime yönelik birtakım sorunlar yaşadıkları sonucuna ulaşılmaktadır. Yetişkinlik yıllarında tüketime ilişkin problemlerin yaşanmaması, bireylerin bilinçli tüketim becerisini bir kişilik haline dönüştürebilmeleri adına verilecek eğitim önemliyken, bu eğitim için çocukluk yıllarının kritik bir süreç olduğu düşünülmektedir. Bu yıllarda en temel öğretim basamağı olan ilkokul çağı bu bilincin kazandırılması adına oldukça önemlidir. İlkokul yıllarından itibaren tüketim bilincini içselleştirmiş bireylerin yetişmesi adına ilkokul programlarının tüketici eğitimi konularıyla desteklenmesi gerekmektedir. $\mathrm{Bu}$ bakımdan ülkemizde yürütülen örgün eğitim faaliyetlerinin tüketici eğitimine yönelik düzenlemeleri de kapsayacak biçimde ele alınması son derece önemli görülmektedir.

Araştırmanın bulgular doğrultusunda bazı öneriler getirilmiştir. Buna göre;

- İlkokullarda uygulanan öğretim programları tüketici eğitimi konularını da içine alacak biçimde, öğrencilere somut yaşantılar sağlayarak disiplinler arası bir yaklaşımla geliştirilebilir.

- Öğrencilerin tüketim bilinç düzeylerinin gelişimini sağlamak adına okul-aile işbirliğini geliştirici çalışmalar gerçekleştirilebilir. Tüketici eğitimi kapsamında okul-aile işbirliğinin bir boyutu olarak ailelere tüketici eğitimi verilebilir.

- Öğretmenlerin, öğrencilerin tüketim bilinç düzeyini geliştirme çabalarına yönelik farkındalıklarını arttırıcı eğitimler verilebilir.

Tüketim bilinci konusunda çalışma yapmak isteyen araştırmacılar için bazı öneriler getirilmiştir. Buna göre;

- Sosyoekonomik düzey ve tüketim bilinci arasındaki ilişkiyi derinlemesine anlamayı sağlayacak araştırmalar desenlenebilir.

- İlkokul öğrencilerinin tüketici olarak sosyalleşmelerinde etkili olduğu düşünülen diğer değişkenleri de (yaş, arkadaş çevresi, kitle iletişim araçları, teknoloji) içine alan çalışmalar gerçekleştirilebilir.

- Eğitim ortamlarının öğrencilerin tüketim bilinci ve davranışlarını geliştirici yönde düzenlendiği, bu bağlamda öğrencinin okul yaşantısı içinde olduğu, kendisi ve çevresindekilerin bilinçli tüketim davranışlarını uygulayabileceği ve gözlemleyebileceği, okul yönetimine katılımının mümkün olduğu, öğrenciyi okul yaşam alanını düzenlerken karar alma noktasına koyan bir eğitim anlayışına yönelik çalışmalar desenlenebilir.

\section{Kaynakça}

Abramovitch, R., Freedman, J. L., \& Pliner, P. (1991). Children and money: getting an allowance, credit versus cash and knowledge of pricing. Journal of Economic Psychology, 12, 27-45.

Aktaş, H., Özüpek, M. N. ve Altunbaş, H. (2011). Çocukların marka tercihleri ve medya tüketim alışkanlıkları. Selçuk Üniversitesi Iletişim Fakültesi Dergisi, 6(4), 115-125.

Akturan, U. (2010). Hedonik tüketim eğiliminin plansız satın alma eğilimi üzerindeki etkisinin belirlenmesi. Öneri, 9(33), 109-116.

Akyüz, Z. (2009). İlköğretim çă̆ındaki öğrencilerin tüketim davranışları ve tüketicilik bilinç düzeyleri. Yayınlanmamış Yüksek Lisans Tezi. Ankara: Gazi Üniversitesi, Eğitim Bilimleri Enstitüsü.

Altık, N. (2010). Illköğretim programlarının bilinçli tüketici davranışlarını kazandırma düzeyine ilişkin bir araştırma. Yayınlanmamış Doktora Tezi. Ankara: Hacettepe Üniversitesi, Sosyal Bilimler Enstitüsü.

Arıkan, R. ve Odabaşı, Y. (1994). Tüketici bilgisine ilişkin temel kavramlar. H. Gürgen (Editör), Tüketici davranışlar ve tüketici bilinci içinde (s. 1-16). Eskişehir: Anadolu Üniversitesi Yayınları.

Ateşoğlu, İ. ve Türkkahraman, M. (2009). Çocukların tüketici olarak sosyalleşmesi. Süleyman Demirel Üniversitesi İktisadi ve İdari Bilimler Fakültesi Dergisi, 14(3), 215-228.

Aydın, M. (1981). Ticaretin düzenlenmesi ve tüketicinin korunması. Ankara: Yonca Yayınları.

Babaoğul, M. ve Şener, A. (2007). Tüketici yazlları I. Ankara: Tüpadem Yayınları.

Babaoğul, M., Aydıner, A. ve Erberber, M. (1999). İlköğretim çağındaki çocukların içinde bulundukları iletişim ortamlarının tüketici olarak sosyalleşmelerine etkisi. Standart Dergisi, 456, 46-53.

Babaoğul, M. ve Öztop, H. (1997). Tüketicilerin, tüketicinin korunmasına ilişkin bilgi ve görüşlerin saptanmas1, Standart Dergisi, 431, 92-106.

Baykul, Y. ve Adıgüzel, O. C. (2013). Sosyal bilimler için istatistik: SPSS uygulamaları. Ankara: Pegem Akademi Yayınları.

Ceylan, Ö. (2010). Tüketicilerin çevresel sürdürülebilirlik ve ekolojik moda konusunda bilgi düzeyi, tutum ve davranışlarının belirlenmesine yönelik bir araştırma. Yayınlanmamış Yüksek Lisans Tezi. Eskişehir: Anadolu Üniversitesi, Sosyal Bilimler Enstitüsü.

Cram, F., \& Ng, S. H. (1999). Consumer socialization. International Association of Applied Psychology, 48(3), 297-312.

Creswell, J. W. (2003). Research design: Qualitative, quantitative, and mixed methods approaches. (2nd edt.) CA: Sage Publication. 
Creswell, J. W. (1999). Mixed-methods research: Introduction and aplication. G. J. Cizek (Ed.), In Handbook Of Educational Policy (p. 455-472). San Diego: Academic Press.

Çavuşoğlu, N. (2006). Meslek lisesi öğretmenlerinin tüketici eğitimi konusundaki bilgi ve davranışlarının incelenmesi. Yayınlanmamış Yüksek Lisans Tezi. Ankara: Ankara Üniversitesi, Fen Bilimleri Enstitüsü.

Çiftçi, S. (2013). Tüketim bilincinin oluşumunu etkileyen çevresel ve bireysel faktörler. M. Yavaşi (Editör), Tüketim bilinci bilinçli tüketici içinde (s. 26-49). Eskişehir: Anadolu Üniversitesi Yayınları.

Dursun, Y. (1993). Gençlerin tüketicilik rolünü kazanmaları. Yayınlanmamış Doktora Tezi. Kayseri: Erciyes Üniversitesi, Sosyal Bilimler Enstitüsü.

Erer, A. S. (2010). Tüketicilerin sosyal sorumluluklar bağlamında şikayet davranışları: sanayi ve ticaret bakanlığ verilerine dayall nitel bir araştırma. Yayınlanmamış Yüksek Lisans Tezi. Ankara: Başkent Üniversitesi, Sosyal Bilimler Enstitüsü.

Ersoy, A. F., Demirci, A. ve Ersoy, S. (2007). Çocukların tüketim davranışlarına anne babaların etkisi. Üçüncü Sektör Kooperatifçilik Dergisi, 42(1), 86-102.

Ersoy, S. ve Nazik, M. H. (2006). Ergenlerde tüketicilik bilinç düzeyi üzerine bir inceleme. Selçuk Üniversitesi Sosyal Bilimler Enstitüsü Dergisi, 16, 313-328.

Ersoy, S. (2005). Illköğretim ögrrencilerinin tüketici eğitimine yönelik bilgi ve tutum düzeyleri. Yayınlanmamış Doktora Tezi. Ankara: Gazi Üniversitesi, Eğitim Bilimleri Enstitüsü.

Ferman, M. (1993). Tüketicinin korunmass meselesine gelişimci bir yaklaşım. İstanbul: İstanbul Ticaret Odası Yayınlar1.

Fraenkel, J. R., Wallen, N. E., \& Hyun, H. H. (2012). How to design and evaluate research in education (8th edt.). New York: McGram-Hill Companies.

Gay, L. R. (1987). Educational research competencies for analysis and application. (3th edt.). London: Merrill Publishing Company.

Gürdal, T. (2003). Kitle iletişim araçlarının farklı sosyoekonomik özelliklerdeki tüketicilerin tüketici ĕ̌itimi konusundaki bilgi ve davranışlarına etkisi. Yayınlanmamış Yüksek Lisans Tezi. Ankara: Hacettepe Üniversitesi, Sağlık Bilimleri Enstitüsü.

Hayta, A. B. (2006). Tüketici haklarının tüketici eğitimindeki rolü. Gazi Üniversitesi Eğitim Fakültesi Dergisi, 26(3), 239-250.

Hekimci, F. (2003). Tüketici, kalite, verimlilik ve yurttaş mutluluğu. 3. Kalite Sempozyumu Bildiriler Kitab1, Bursa: TMMOB Makine Mühendisleri Odası, s. 72-79.

Huck, S. W. (2008). Reading statistics and research. Boston: Pearson.

John, D. R. (1999). Consumer socialization of chinese children: A retrospective look at twenty-five years of research. Journal of Consumer Research, 26(3), 183213.
Johnson, R. B., \& Onwuegbuzie, A. J. (2004). Mixed methods research: A research paradigm whose time has come. Educational Research, 33(7), 14-26.

Kahyaoğlu, M. ve Kırıktaş, H. (2013). The research of the relationship between primary school students' enviromentally resposible behaviors and conscious consumer behaviors. International Journal of Educational Research and Technology, 4(3), 1-8.

Karabacak, E. (1993). Medyanın tüketici davranışları üzerindeki etkisi ve pazarlama yönetimi açısından önemi. Yayınlanmamış Yüksek Lisans Tezi. Konya: Selçuk Üniversitesi, Sosyal Bilimler Enstitüsü.

Karaman, K. Y. ve Ökdem, M. (2013). Consumer right in elementary school life studies and social studies textbooks. Elementary Education Online, 12(3), 674686.

Karsu, S. (2013). Tüketici bilinci ve bilinçli tüketim. M. Yavaşi (Editör), Tüketim bilinci bilinçli tüketici içinde (s. 98-119). Eskişehir: Anadolu Üniversitesi Yayınları.

Kırc1, H. (2014). Hedonik tüketim davranışları ve toplumsal etkileri. Paradoks Ekonomi, Sosyoloji ve Politika Dergisi, 10(1), 80-100.

Kor, Ö. (2007). Türkiye'de ve Avrupa Birliği'nde uygulanan tüketiciyi koruma politikalart ekseninde tüketici bilincini ölçmeye yönelik Mersin'de yapılan bir alan araştırması. Yayınlanmamış Yüksek Lisans Tezi. Mersin: Mersin Üniversitesi, Sosyal Bilimler Enstitüsü.

Leech, N. L., \& Onwuegbuzie, A. J. (2009). A typology of mixed methods research designs. Qual Quant, 43(2), 265-275.

Liamputtong, P. (2009). Qualitative data analysis: Conceptual and practical considerations. Health Promotion Journal of Australia, 20(2), 133-139.

Makela, C. J., \& Peters, S. (2004). Consumer education: Creating consumer awareness among adolescents in botswana. International Journal of Consumer Studies, 28(4), 379-387.

Mcneal, J. U. (1992). Kids as costumers: A handbook of marketing to children. New York: Lexington Books.

MEB (2005). Sosyal Bilgiler Dersi İlköğretim 4. ve 5. Sinıf Programı ve Kılavuzu. Talim ve Terbiye Kurulu Başkanlığı: Ankara.

MEB (2009a). Ilköğretim Matematik Dersi 1-5. Sınıflar Ögrretim Programı ve Kllavuzu. Talim ve Terbiye Kurulu Başkanlığı: Ankara.

MEB (2009b). Ilkögrretim 1. 2. ve 3. Sinıflar Hayat Bilgisi Dersi Ögretim Programı ve Kılavuzu. Talim ve Terbiye Kurulu Başkanlığı: Ankara.

MEB (2009c). Ilköğretim Türkçe Dersi Öğretim Programı ve Kılavuzu. Talim ve Terbiye Kurulu Başkanlığı: Ankara.

MEB (2012). Oyun ve Fiziki Etkinlikler Dersi Öğretim Programı (İlkokul 1-4. Sinıflar). Temel Eğitim Müdürlüğü: Ankara. 
MEB (2013). Ilköğretim Kurumlarl (İlkokullar ve Ortaokullar) Fen Bilimleri Dersi (3-8. sinıflar) Öğretim Programları. Talim ve Terbiye Kurulu Başkanlığı: Ankara.

Miles, M. B., \& Huberman, A. M. (1994) An expanded sorucebook qualitative analysis. (2. Edt). California: Sage Publication.

Morse, J. M. (2003) Principles of mized methods and multimethod researc design. A. Tashakkori and C. Teddlie (Eds.), In Handbook of Mixed Methods In Social and Behavioral Research (p. 189-208). CA: Sage Publications.

Morse, J. (1991). Negotiating commitment and involvement in the nurse-patient relationship. Journal of Advanced Nursing, 16(4), 455-468.

Moschis, G. P., \& Moore, R. L. (1979). Decision making among the young: a socialization perspective. Journal of Consumer Research, 6(2), 101-112.

Moschis, G. P., \& Churchill G. A. (1978), Consumer socialization: a theoretical and empirical analysis. Journal of Marketing Research, 15(4), 599-609.

Nazik, M. H. ve Şanlıer, N. (2001). Ailelerin tüketim davranışlarına reklamların etkisinin tespiti üzerine bir araştırma. Standart Dergisi, 476, 80-87.

Ortabostan, Ş. (1999). Gecekondu bölgelerinde ev kadınlarına yönelik tüketici eğitimi programı kapsamının belirlenmesi üzerinde bir araştırma. Yayınlanmamış Yüksek Lisans Tezi. Ankara: Ankara Üniversitesi, Fen Bilimleri Enstitüsü.

Özbölük, T. (2010). Pazarlamada bilinçli tüketim ve tüketicilerin bilinçli tüketime ilişkin tutumlarının belirlenmesine yönelik bir araştırma. Yayınlanmamış Yüksek Lisans Tezi. Sivas: Cumhuriyet Üniversitesi Sosyal Bilimler Enstitüsü.

Özdemir, Ş. (2007). Hazcl (hedonik) tüketim davranışlarında televizyonun rolü: SDÜ ögrencileri üzerine bir araștırma. Yayınlanmamış Yüksek Lisans Tezi. Isparta: Süleyman Demirel Üniversitesi, Sosyal Bilimler Enstitüsü.

Özgen, Ö. (1995). Tüketicinin sosyalleştirilmesine yaşam dönemi yaklaşımı. Standart Dergisi, 402, 85-91.

Peker, S. (1993). Yetişkin tüketicilerin tüketici ĕgitimi ihtiyaçları. Yayınlanmamış Doktora Tezi. İstanbul: İstanbul Üniversitesi, Sosyal Bilimler Enstitüsü.

Pınarcı, G. G. (2007). İlköğretim öğrencilerine farklı yöntemlerle verilen tüketici eğitiminin etkisinin belirlenmesi. Yayınlanmamış Yüksek Lisans Tezi. Ankara: Gazi Üniversitesi, Eğitim Bilimleri Enstitüsü.

Purutçuoğlu, E. (2003). Lise öğrencilerinin tüketici ĕgitimi ihtiyacının belirlenmesi. Yayınlanmamış Yüksek Lisans Tezi. Ankara: Ankara Üniversitesi, Fen Bilimleri Enstitüsü.

Riesman, D., Glazer, N., \& Denny. R. (1950). The lonely crowd, new haven. Yale University Press.

Şahin, Ç. F. (2005). Tüketim toplumu ve Türkiye'de tüketim toplumunun yaratılması süreci. Yayınlanmamış Yüksek
Lisans Tezi. İstanbul: Marmara Üniversitesi, Sosyal Bilimler Enstitüsü.

Sağlam, H. İ. (2010a). Bilinçli tüketicilik düzeyi ölçeği çalışması. International Journal of Human Sciences, 7(1), 1190-1200.

Sağlam, H. İ. (2010b). İlköğretim öğrencilerinin bilinçli tüketicilik düzeylerinin çeşitli değişkenler açısından incelenmesi. Kuram ve Uygulamada Ĕ̌itim Bilimleri, 10(4), 2553-2568.

Sert, P. (2002). Illköğretim öğrencilerinin tüketici davranışları. Yayınlanmamış Yüksek lisans Tezi. Ankara: Gazi Üniversitesi, Eğitim Bilimleri Enstitüsü.

Taluğ, C. ve Birden, B. (2014). Sürdürülebilir üretim ve tüketim. Türkiye Biyoetik Dergisi, 1(2), 78-91.

Teddlie, C., \& Yu, F. (2007). Mixed methods sampling: A typology with examples. Journal of Mixed Methods Research, 1(1), 77-100.

Terzi, H. (2012). Türkiye'de tüketim kültürünün gelişim süreci ve Türk tüketicilerin tüketim davranışları üzerine etkisi: Karabük ili örneği. Yayınlanmamış Yüksek Lisans Tezi. Karabük: Karabük Üniversitesi, Sosyal Bilimler Enstitüsü.

Tüketicinin Korunması Hakkında Kanun. (2013, 28 Kasım). Resmi Gazete (Sayı: 29223). Erişim adresi: http://www.mevzuat.gov.tr/MevzuatMetin/1.5.6502.pdf

United Nations (2003). United Nations guidelines for consumer protection, New York: UNDESA.

Ünay, H. (2012). Ilkögrretim öğrencilerine verilen tüketici ĕgitiminin gösterişçi tüketimi önlemedeki etkisinin incelenmesi. Yayınlanmamış Yüksek Lisans Tezi. Ankara: Gazi Üniversitesi, Eğitim Bilimleri Enstitüsü.

Varcoe, K. P., Peterson, S., Garrett, C., Martin, A., Rene, P., \& Costello, C. (2001). What teens want to know about financal management. Journal of Family and Consumer Sciences, 93(2), 30-34.

Verma, D. P. S., \& Kapoor, N. (2004), Influence of tv advertisements on children's buying response: Role of parent-child interaction, Global Business Review, 5(1), 51-71.

Ward, S. (1974). Consumer socialization. Journal of Consumer Research, 1(2), 1-14.

World Wildlife Fund (2012). Türkiye'nin ekolojik ayak izi raporu. İstanbul: Ofset Yapımevi.

Yaman, G. (2002). Pazarlamada tüketici bilinci ve bilinçli tüketici: Sakarya ili uygulaması. Yayınlanmamış Yüksek Lisans Tezi. Sakarya: Sakarya Üniversitesi, Sosyal Bilimler Enstitüsü.

Yaşar, Ş., Sözer, E. ve Gültekin, M. (2000). Ilköğretimde ögrrenme-ögretme süreci ve öğretmenin rolü. 8. Ulusal Eğitim Bilimleri Kongresi Bildiriler Kitabı. Trabzon: Karadeniz Teknik Üniversitesi, s. 452-461.

Yener, M. (1990). Tüketici eğitimi ve aile açısından önemi. Standart Dergisi, 346, 19-21.

Yıldırım, A. ve Şimşek, H. (2011). Sosyal bilimlerde nitel araştırma yöntemleri. Ankara: Seçkin Yayıncılık. 